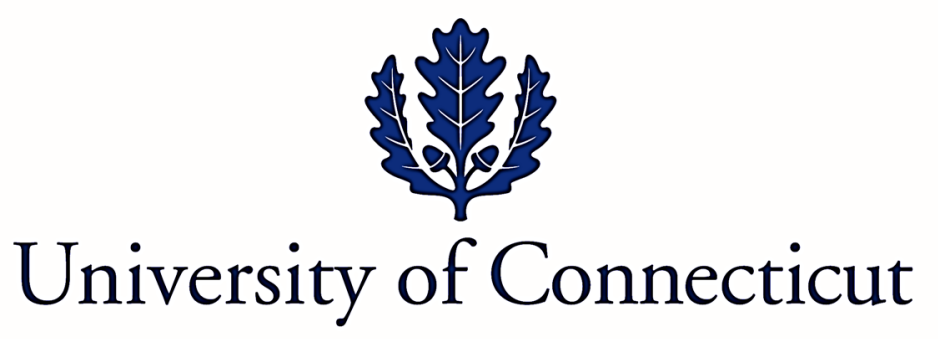

Department of Economics Working Paper Series

Causality between Output and Income Inequality across U.S. States:

Evidence from a Heterogeneous Mixed Panel Approach

by

Shinhye Chang

University of Pretoria

Hsiao-Ping Chu

Ling-Tung University

Rangan Gupta

University of Pretoria

Stephen M. Miller

University of Nevada - Las Vegas

Working Paper 2018-07

June 2018

365 Fairfield Way, Unit 1063

Storrs, CT 06269-1063

Phone: (860) 486-3022

Fax: (860) 486-4463

http://www.econ.uconn.edu/

This working paper is indexed in RePEc, http://repec.org 


\title{
Causality between Output and Income Inequality across U.S. States: Evidence from a Heterogeneous Mixed Panel Approach \\ Shinhye Chang, ${ }^{a}$ Hsiao-Ping Chu, ${ }^{\mathrm{b}}$ Rangan Gupta, ${ }^{\mathrm{c}}$ and Stephen M. Miller ${ }^{\mathrm{d}}$
}

\begin{abstract}
In this paper, we investigate the causal relationship between output, proxied by personal income, and income inequality in a panel data of 48 states from 1929 to 2012 . We employ the causality methodology proposed by Emirmahmutoglu and Kose (2011), as it incorporates possible slope heterogeneity and cross-sectional dependence in a multivariate panel. Evidence of bi-directional causal relationship exists for several inequality measures -- the Atkinson Index, Gini Coefficient, the Relative Mean Deviation, Theil's entropy Index and Top $10 \%$-- but no evidence of the causal relationship for the Top $1 \%$ measure. Also, this paper finds state-specific causal relationships between personal income and inequality.
\end{abstract}

JEL classification code: $\quad$ C33, D31, D63

Keywords:

Income inequality, Panel data, Personal Income, Granger causality

\footnotetext{
${ }^{a}$ Department of Economics, University of Pretoria, Pretoria, 0002, South Africa. Email: c.shin.h@gmail.com.

${ }^{\mathrm{b}}$ Department of Business Administration, Ling-Tung University, Taichung, Taiwan. Email: clare@teamail.ltu.edu.tw.

${ }^{c}$ Department of Economics, University of Pretoria, Pretoria, 0002, South Africa. Email: rangan.gupta@up.ac.za.

${ }^{\mathrm{d}}$ Corresponding author. Department of Economics, Lee Business School, University of Nevada, Las Vegas, 4505 Maryland Parkway, Box 456005, Las Vegas, NV 89154-6005, USA. Email: stephen.miller@unlv.edu.
} 


\section{Introduction}

The issue of income inequality has drawn great interest from researchers, politicians, and policy makers, since the well-being of an individual often depends on the distribution of income. Many researchers show that the U.S. economy experienced increasing income inequality over the last 30 years. Consequently, the determinants of income inequality and political and/or economic solutions to reduce inequality have become important discussions.

Researchers consider many possible explanations for this widening gap, yet no consensus exists on what can explain its emergence and on what can reduce differences among individuals. Most of the existing literature examines the effects of income inequality on economic growth in personal income, since personal income exerts a large effect on consumer consumption, and since consumer spending drives much of the economy. Studies provide evidence that more income inequality slows economic growth over the medium and long terms (Alesina and Perotti, 1996; Alesina and Rodrik, 1994; Person and Tabellini, 1992; Birdsall et al., 1995; Clarke, 1995; Deininger and Squire, 1996; Easterly, 2007; Wilkinson and Pickett, 2007; Berg et al., 2012). In contrast, some studies provide evidence that more income inequality promotes economic growth (Lazear and Rosen, 1981; Hassler and Mora, 2000; Kaldor, 1955; Bourguignon 1981; Saint-Pal and Verdier, 1993; Barro, 2000). Depending on the specific research method and sample, this literature discovers a complex set of interactions between inequality and economic growth and highlights the difficulty of capturing a definitive causal relationship. Inequality either promotes, slows, or does not affect growth.

Studies also exist that examines the causality between income growth and inequality using panel data. Using cross-country data, Dollar and Kraay (2002) document that the share of income going to the poorest fifth of the income distribution does not change when mean income fluctuates. Their finding implies that income of the poor grows at the same rate as the 
growth rate of the economy. On the other hand, Parker and Vissing-Jorgensen (2009), using U.S. income tax returns, find that the top-end of the income distribution carries a high share of aggregate income fluctuations. Although inequality rose in almost all U.S. states and regions between 1980 and the present, some states and regions experienced substantially greater increases in inequality than did others (see, for example, Partridge et al., 1996; Partridge et al., 1998; Morrill, 2000). The decentralisation of the analysis to states and regions allows geographic policy differences to emerge. At the same time, a cross-state consistency also can exist in how those policies respond to the macroeconomic economic shocks such as the Great Recession. Although many researchers analyse state differences in poverty, health insurance, social mobility, and taxes, less study occurs on state differences in causality between personal income and inequality.

Even though many researchers analyse causality relationships using cross-state data, a couple of issues are not addressed such as the possible existence of heterogeneity, crosssectional dependence, and interdependencies. We use a modified version of the panel causality developed by Emirmahmutoglu and Kose (2011), which was originally designed to analyse causality in a bivariate-setting, to control not only for heterogeneity and crosssectional dependence across state, but also to permit interactions between personal income and inequality.

Since U.S. states experience significant spatial effects given their high level of integration, we need to address the concern expressed in Pesaran (2004), who notes that ignoring cross-sectional dependency may lead to substantial bias and size distortions. Furthermore, unlike traditional causality approaches that rely on cointegration techniques, the bootstrap methodology does not require testing for cointegration, hence obviating pre-test bias (Emirmahmutoglu and Kose, 2011). The bootstrap methodology also provides evidence for the entire panel as well as each of the cross-sectional units comprising the panel. Thus, we 
can consider state-specific policies, since we possess causality test results for each of the series in the panel. A multivariate panel setup allows for greater inference due to the greater degrees of freedom, stemming from the larger data set that a panel provides. The panel also allows us to control for omitted variables.

Our sample period covers a series of different events - the Great Depression (19291944), the Great Compression (1945-1979), the Great Divergence (1980-present), the Great Moderation (1982-2007) and the Great Recession (2007-2009). Goldin and Margo (1991) categorized the Great Compression as the time after the Great Depression, when income inequality fell significantly compared to the Great Depression. Krugman (2007) identified the period after the Great Compression as the Great Divergence, when income inequality grew. Piketty and Saez (2003) argue that the Great Compression ended in the 1970s and then income inequality worsened in the United States. Many studies show high income inequality during the 1920s, strong growth and shared prosperity for the early post-war period, followed by slower growth and growing inequality since the $1970 \mathrm{~s}^{1}$.

This paper is structured as follows. Section 2 describes data. Section 3 discusses the methodology. Section 4 reports and analyses the empirical results. Concluding remarks appear in Section 5.

\section{Data}

Our analysis relies on the natural logarithm of U.S. per capita real personal income and the six income inequality measures ${ }^{2}$ - Atkinson Index, Gini Coefficient, the Relative Mean Deviation, Theil's entropy Index, the Top 10\% income share, and the Top 1\% income share - as proxies for inequality across the income distribution (Leigh, 2007). The annual data cover 1929 - 2012. Income inequality measures and income share measures come from the

\footnotetext{
${ }^{1}$ For example, see Dew-Becker and Gordon (2005), Gordon (2009)

${ }^{2}$ We take natural logarithms to correct for potential heteroskedasticity and dimensional differences between the series. Also, by taking natural logarithms, we can interpret the coefficients as elasticities.
} 
online data segment of Professor Mark W. Frank's website. ${ }^{3}$ U.S. per capita nominal personal income comes from the Bureau of Economic Analysis (BEA), which we deflate using the U.S. aggregate Consumer Price Index (Index 1982-84=100). By using cross-state panel data, we minimize the problems associated with data comparability often encountered in crosscountry studies related to income inequality.

\section{Methodology}

As we use cross-state panel dataset, cross-sectional dependency may create some bias in identifying causal linkages between personal income and inequality. The high degree of economic integration across U.S. states can cause spillover effects of shocks originating in one state to other states and these effects, if ignored, may produce misleading inferences due to misspecification. Also, the homogeneity restriction, which imposes constant parameters with cross-section-specific characteristics, can produce similar outcomes (Granger, 2003; Breitung, 2005). To determine the appropriate specification, we test for cross-sectional dependence and slope homogeneity.

\subsection{Testing for cross-sectional dependence}

To test for cross-sectional dependence, researchers typically use the Lagrange Multiplier (LM) test of Breusch and Pagan (1980). To compute the $L M$ test, we implement the following panel-data estimation:

$$
y_{i t}=\alpha_{i}+\beta_{i}^{\prime} x_{i t}+u_{i t} \text { for } i=1,2, \ldots, N ; t=1,2, \ldots, T
$$

where $i$ is the cross-section dimension, $t$ is the time dimension, $x_{i t}$ is $k \times 1$ vector of expnatory variables, $\alpha_{i}$ and $\beta_{i}$ are the individual intercepts and slope coefficients that we allow to vary across states, respectively. In the $L M$ test, we test the null hypothesis of nocross-sectional dependence -- $H_{0}: \operatorname{Cov}\left(u_{i t}, u_{j t}\right)=0$ for all $t$ and $i \neq j--$ against the

\footnotetext{
${ }^{3}$ http://www.shsu.edu/eco_mwf/inequality.html. Professor Frank constructed the dataset based on Internal Revenue Service (IRS) data, which omits some individuals earning less than a threshold level of gross income. For this reason, we focus more on the top income shares as primary indicators of inequality measures. We examine six inequality measures as each offers a different insight as to the inequality of income.
} 
alternative hypothesis of cross-sectional dependence $H_{1}: \operatorname{Cov}\left(u_{i t}, u_{j t}\right) \neq 0$, for at least one pair of $i \neq j$. To test the null hypothesis, Breusch and Pagan (1980) developed the $L M$ test as follows:

$$
L M=T \sum_{i=1}^{N-1} \sum_{j=i+1}^{N} \hat{\rho}_{i j}^{2}
$$

where $\hat{\rho}_{i j}$ is the sample estimate of the pair-wise correlation of the residuals from Ordinary Least Squares (OLS) estimation of equation (1) for each $i$. Under the null hypothesis, the $L M$ statistics possesses an asymptotic chi-squared distribution with $\left(\frac{N(N-1)}{2}\right)$ degrees of freedom. Note that the $L M$ test is valid for $N$ relatively small and $T$ sufficiently large.

The Cross-sectional Dependence $(C D)$ test may decrease in power under certain situations -- when the population average pair-wise correlations are zero, but the underlying individual population pair-wise correlations are non-zero (Pesaran et al., 2008). In addition, in stationary dynamic panel data models, the $C D$ test fails to reject the null hypothesis when the factor loadings contain zero mean in the cross-sectional dimension. To overcome these problems, Pesaran et al. (2008) propose a bias-adjusted test, which is a modified version of the $L M$ test by using the exact mean and variance of the $L M$ statistic. The bias-adjusted $L M$ test is

$$
\left.L M_{a d j}=\sqrt{\left(\frac{2 T}{N(N-1)}\right)}\right) \sum_{I=1}^{N-1} \sum_{j=i+1}^{N} \hat{\rho}_{i j} \frac{(T-k) \hat{\rho}_{i j}^{2}-\mu_{T i j}}{\sqrt{v_{T i j}^{2}}}
$$

where $\mu_{T i j}$ and $v_{T i j}^{2}$ are the exact mean and variance of $(T-k) \hat{\rho}_{i j}^{2}$, respectively, which Pesaran et al. (2008) provides. Under the null hypothesis with first $T \rightarrow \infty$ and $N \rightarrow$ $\infty$, the $L M_{a d j}$ test is asymptotically normally distributed.

\subsection{Testing slope homogeneity}

We next check whether the slope coefficients are homogeneous in a panel data analysis. The causality from one to another variable with the joint restriction imposed for entire panel generates the strong null hypothesis (Granger, 2003). Moreover, the homogeneity assumption 
for the parameters cannot capture heterogeneity due to region-specific characteristics (Breitung, 2005).

The most well-known way to test the null hypothesis of slope homogeneity -$H_{0}: \beta_{i}=\beta$ for all $i$-- against the hypothesis of heterogeneity -- $H_{1}: \beta_{i} \neq \beta$ for a non-zero fraction of pair-wise slopes for $i \neq j$-- employs the standard $F$ test. The $F$ test is valid when the cross-section dimension $(N)$ of the panel is relatively small and the time dimension $(T)$ is relatively large; the explanatory variables are strictly exogenous; and the error variances are homoscedastic. By relaxing the homoscedasticity assumption in the $F$ test, Swamy (1970) developed the slope homogeneity test on the dispersion of individual slope estimates from a suitable pooled estimator. Both the $F$ and Swamy's test require panel data, where $N$ is small relative to $T$. Pesaran and Yamagata (2008) proposed a standardized version of Swamy's test (the $\tilde{\Delta}$ test) for testing slope homogeneity in large panels. The $\tilde{\Delta}$ test is valid when $(N, T) \rightarrow$ $\infty$ without any restrictions on the relative expansion rates of $N$ and $T$ as the error terms are normally distributed. In the $\tilde{\Delta}$ test approach, the first step computes the following modified version of the Swamy's test as in Pesaran and Yamagata $(2008)^{4}$ :

$$
\tilde{S}=\sum_{i=1}^{N}\left(\tilde{\beta}_{i}-\tilde{\beta}_{W F E}\right)^{\prime} \frac{x_{i}^{\prime} M_{\tau} x_{i}}{\tilde{\sigma}_{i}^{2}}\left(\tilde{\beta}_{i}-\tilde{\beta}_{W F E}\right)
$$

where $\tilde{\beta}_{i}$ is the pooled OLS estimatoer, $\widetilde{\beta}_{W F E}$ is the weighted fixed effect pooled estimator, $M_{\tau}$ is an identity matrix, and $\tilde{\sigma}_{i}^{2}$ is the estimator of $\sigma_{i}^{2}$. Then the standardized dispersion statistic is as follows:

$$
\tilde{\Delta}=\sqrt{N}\left(\frac{N^{-1} \tilde{S}-k}{\sqrt{2 k}}\right)
$$

Under the null hypothesis with the condition of $(N, T) \rightarrow \infty$ (as long as $\sqrt{N} / T \rightarrow \infty$ ) and the error terms are normally distributed, the $\tilde{\Delta}$ test is asymptotically normally distributed. Under the normally distributed errors, the small sample properties of the $\tilde{\Delta}$ test improve when using

\footnotetext{
${ }^{4}$ See Pesaran and Yamagata (2008) for the details of estimators and for Swamy's test.
} 
the following bias-adjusted version:

$$
\tilde{\Delta}_{a d j}=\sqrt{N}\left(\frac{N^{-1} \tilde{S}-E\left(\tilde{z}_{i t}\right)}{\sqrt{\operatorname{var}\left(\tilde{z}_{i t}\right)}}\right)
$$

where $E\left(\tilde{z}_{i t}\right)=k$ and $\operatorname{var}\left(\tilde{z}_{i t}\right)=2 k(T-k-1) / T+1$.

If cross-sectional dependence and heterogeneity exist, then the panel causality test that imposes the homogeneity restriction and does not account for spillover effects may produce misleading inferences. Table 1 summarizes the results of these selected tests. We can reject the nulls of slope homogeneity and cross-sectional independence, hence, confirming the evidence of heterogeneity as well as spillover effects across the U.S. states. The findings reported in Table 1 motivate the decision to rely on the methodology for causal analysis proposed by Emirmahmutoglu and Kose (2011), which addresses heterogeneous mixed panels and cross-sectional dependence.

\subsection{Panel Granger causality analysis}

The panel Granger causality test proposed by Emirmahmutoglu and Kose (2011) uses the Meta analysis of Fisher (1932). Emirmahmutoglu and Kose (2011) extend the Lag Augmented VAR (LA-VAR) approach by Toda and Yamamoto (1995), which uses the level VAR model with extra $d$ max lags to test Granger causality between variables in heterogeneous mixed panels. Consider a level VAR model with $k_{i}+d \max _{i}$ lags in heterogeneous mixed panels:

$$
\begin{aligned}
& x_{i, t}=\mu_{i}^{x}+\sum_{j=1}^{k_{i}+d \max _{i}} A_{11, i j} x_{i, t-j}+\sum_{j=1}^{k_{i}+d \max _{i}} A_{12, i j} y_{i, t-j}+u_{i, t}^{x} \text { and } \\
& y_{i, t}=\mu_{i}^{y}+\sum_{j=1}^{k_{i}+d \max _{i}} A_{21, i j} x_{i, t-j}+\sum_{j=1}^{k_{i}+d \max _{i}} A_{22, i j} y_{i, t-j}+u_{i, t}^{y},
\end{aligned}
$$

where $i(i=1, \ldots, N)$ denotes individual cross-sectional units; $t(t=1, \ldots, T)$ denotes time period; $\mu_{i}^{x}$ and $\mu_{i}^{y}$ are two vectors of fixed effects; $u_{i, t}^{x}$ and $u_{i, t}^{y}$ are column vectors of error terms; $k_{i}$ is the lag structure, which we assume to know and may differ across cross-sectional 
units; and $d \max _{i}$ is the maximal order of integration in the system for each $i$. Following the bootstrap procedure in Emirmahmutoglu and Kose (2011), we test for causality from $x$ to $y$ as follows:

Step 1. We determine the maximal order $d \max _{i}$ of integration of variables in the system for each cross-section unit based on the Augmented Dickey Fuller (ADF) unit-root test and select the lag orders $k_{i}$ 's via Akaike information criterion or Schwarz information criterion (AIC or SIC) by estimating the regression (2) using the OLS method.

Step 2. We re-estimate Equation (2) using the $d \max _{i}$ and $k_{i}$ under the non-causality hypothesis and attain the residuals for each individual as follows:

$$
\hat{u}_{i, t}^{y}=y_{i, t}-\hat{\mu}_{i}^{y}-\sum_{j=1}^{k_{i}+d \max _{i}} \hat{A}_{21, i j} x_{i, t-j}-\sum_{j=1}^{k_{i}+d \max _{i}} \hat{A}_{22, i j} y_{i, t-j}
$$

Step 3. We center the residuals using the suggestion of Stine (1987) as follows:

$$
\tilde{u}_{t}=\hat{u}_{t}-(T-k-l-2)^{-1} \sum_{j=1}^{k_{i}+d \max _{i}} \hat{u}_{t}
$$

where $\hat{u}_{t}=\left(\hat{u}_{1 t}, \hat{u}_{2 t}, \ldots, \hat{u}_{N t}\right)^{\prime}, k=\max \left(k_{i}\right)$ and $l=\max \left(d \max _{i}\right)$. Furthermore, we develop the $\left[\tilde{u}_{i t}\right]_{N \times T}$ from these residuals. We select randomly a full column with replacement from the matrix at a time to preserve the cross covariance structure of the errors. We denote the bootstrap residuals as $\tilde{u}_{t}^{*}$ where $(t=1, \ldots, T)$.

Step 4. We generate a bootstrap sample of $y_{i, t}^{*}$ under the null hypothesis:

$$
y_{i, t}^{*}=\hat{\mu}_{i}^{y}+\sum_{j=1}^{k_{i}+d \max _{i}} \hat{A}_{21, i j} x_{i, t-j}+\sum_{j=1}^{k_{i}+d \max _{i}} \hat{A}_{22, i j} y_{i, t-j}^{*}+u_{i, t}^{*},
$$

where $\hat{\mu}_{i}^{y}, \hat{A}_{21, i j}$, and $\hat{A}_{22, i j}$ are the estimates from step 2 .

Step 5. For each individual, we calculate Wald statistics to test for the non-causality null hypothesis by substituting $y_{i, t}^{*}$ for $y_{i, t}$ and estimating Equation (2) without imposing any parameter restrictions. Using individual $p$-values that correspond to the Wald statistic of the $i^{\text {th }}$ individual cross-section, we calculate the Fisher test statistic $\lambda$ as follows:

$$
\lambda=-2 \sum_{i=1}^{N} \ln \left(p_{i}\right), i=1, \ldots, N
$$


We generate the bootstrap empirical distribution of the Fisher test statistics by repeating steps 3 to 510,000 times and specifying the bootstrap critical values by selecting the appropriate percentiles of these sampling distributions. Using simulation studies, Emirmahmutoglu and Kose (2011) demonstrate that the performance of LA-VAR approach under both crosssection independency and dependency seem to perform satisfactory for the entire range of values for $T$ and $N$.

\section{Empirical Analysis}

As mentioned in the methodology section, we first need to examine for possible crosssectional dependence and slope heterogeneity, using four different tests $\left(C D_{B P}, C D_{L M}, C D, L M_{a d j}\right)$ with a null hypothesis of no cross-sectional dependence. The results conclude that we can reject the null hypothesis at the 1-percent level of significance (see Table 1, 4 rows from the top). This outcome implies that evidence exists of crosssectional dependence, meaning that a shock originating in one state may spillover into other states. As shown in the methodology section, the causality tests of Emirmahmutoglu and Kose (2011) control for this dependency.

Also, Table 1 (3 rows from the bottom) shows the results of the slope homogeneity tests. According to $\tilde{\Delta}$ test, we can reject the null hypothesis of homogenous slopes at the 1percent level of significance. Furthermore, at least one of the tests rejects null hypothesis of slope homogeneity with the $\tilde{\Delta}_{a d j}$ test and the Swamy Shat test. This implies that imposing slope homogeneity on the panel causality analysis may result in misinterpretation. Hence, we need to consider possible state-specific characteristics.

Establishing the existence of cross-sectional dependence and heterogeneity across the 48 U.S. states suggests the suitability of the bootstrap panel causality approach developed by Emirmahmutoglu and Kose (2011), which accounts for these econometric issues. Table 2 through 7 report the bootstrap test causality results. We chose the appropriate lag length using the Akaike Information Criterion for each state. 
The overall causality results between income inequality and personal income suggest that we can reject both the null of no Granger causality from inequality to income and from income to inequality at 1-percent level of significance (i.e. bi-directional causality) except for Top $1 \%$ income share, suggesting the possible existence of a trend relationship between increasing income and widening income inequality.

Table 2 shows the causality between personal income and the Atkinson Index. Under AIC and SBC, the asymptotic chi-square values applied with the Fisher test are higher for inequality led hypothesis. This suggests that individual states results are more consistent for the inequality led hypothesis than the income led hypothesis. That is, only 3 states out of 48 display insignificant Wald statistics (high $p$-values) for the inequality led hypothesis, namely New Mexico, North Dakota, and Wyoming. For the income led hypothesis, 6 states display insignificant Wald statistics, namely Arizona, Florida, Maryland, Missouri, New Hampshire, and Wyoming. Thus, Wyoming confirms the neutrality hypothesis.

Table 3 shows causality between personal income and the Gini coefficient. Under AIC and $\mathrm{SBC}$, the asymptotic chi-square values applied with the Fisher test are higher for inequality led hypothesis. This suggests that individual results are more consistent for the inequality led hypothesis than the income led hypothesis. That is, 4 states display insignificant Wald statistics (high $p$-values) for inequality led hypothesis, namely Kansas, Montana, Nebraska, and Wyoming. For the income led hypothesis, 11 states display an insignificant Wald statistics, namely Arkansas, Colorado, Iowa, Louisiana, Maryland, Mississippi, Missouri, South Carolina, Texas, Wisconsin, and Wyoming. Once again, Wyoming confirms to the neutrality hypothesis.

Table 4 shows causality between personal income and the Relative Mean Deviation. Under AIC and SBC, the asymptotic chi-square values applied with the Fisher test are higher for inequality led hypothesis. This suggests that individual results are more consistent for the 
inequality led hypothesis than the income led hypothesis. Only South Dakota displays an insignificant Wald statistic (high $p$-value) for the inequality led hypothesis. For the income led hypothesis, only 3 states out of 48 states display an insignificant Wald statistics, namely Iowa, Texas, and Wyoming. No state conforms to the neutrality hypothesis in this case.

Table 5 shows causality between personal income and Theil's entropy. Under AIC and SBC, the asymptotic chi-square values applied with the Fisher test are higher for the inequality led hypothesis. This suggests that individual results are more consistent for the inequality led hypothesis than the income led hypothesis. 12 states display insignificant Wald statistics (high $p$-values) for the inequality led hypothesis, namely Arkansas, Idaho, Indiana, Maryland, Mississippi, Nebraska, New Mexico, North Carolina, Oregon, South Dakota, Vermont, and Wyoming. For the income led hypothesis, 30 states display an insignificant Wald statistics, namely Arizona, Colorado, Connecticut, Florida, Idaho, Indiana, Iowa, Louisiana, Maryland, Massachusetts, Minnesota, Mississippi, Missouri, Nevada, New Hampshire, New Jersey, New York, North Dakota, Ohio, Oregon, Pennsylvania, South Carolina, South Dakota, Tennessee, Texas, Utah, Vermont, Washington, Wisconsin, and Wyoming. Thus, we confirm the neutrality hypothesis for 8 states, namely, Idaho, Indiana, Maryland, Mississippi, Oregon, South Dakota, Vermont, and Wyoming.

Table 6 shows causality between personal income and Top 10\% income share. 4 states display insignificant Wald statistics (high $p$-values) for the inequality led hypothesis, namely Arizona, Montana, South Dakota, and Wyoming. For the income led hypothesis, 4 states display an insignificant Wald statistics, namely Arizona, Florida, New York, and Utah. Thus, we confirm the neutrality hypothesis only for Arizona.

Table 7 shows that the overall results confirm no causality between Top 1\% income share and Income.

The differences of the results underline the advantages of panel over individual 
regressions such as capturing more complex dynamic models, identifying unobserved effects, and mitigating multicollinearity problems (Baltagi, 2008).

\section{Conclusion}

In this paper, we followed the procedure of Emirmahmutoglu and Kose (2011), a panel Granger causality methodology that controls for heterogeneity and cross-sectional dependence, to test for the existence and direction of causal relationships between income and income inequality, using annual data for the 48 U.S. states from 1929-2012. The panel data literature has shown possible cross-sectional dependence with panel data resulting in biased estimates (Pesaran; 2006).

In this study, we found evidence of bi-directional causal relationship exists for the Atkinson Index, Gini Coefficient, the Relative Mean Deviation, Theil's entropy Index, and Top $10 \%$ measures of inequality. For Top $1 \%$ income share, we found no evidence of a causal relationship. Also, we found state-specific causal relationships between personal income and inequality.

The reason for focusing on inequality across states reflects the fact that inequalityrelated policy can occur at the state and local levels, which can produce different inequality profiles across states. For instance, federal tax and transfer policies affect inequality. States can selectively adopt and/or implement some federal policies or supplement them with state policies. For example, states (and local municipalities) can increase the minimum wage applicable within its borders as seen with the recent adoption of $\$ 15$ minimum wage in some cities. Progressive state personal income tax policies can alter the progressivity of the federal code. As another example, states responded differently to the Affordable Care Act (Obama Care) with respect to providing or not providing Medicaid to state residents.

As another example, most immigrants from Mexico settled in California and Texas and the immigration probably increased inequality. Legalisation of immigration for many U.S. residents would attract those who currently work off the books onto the IRS tax rolls, 
which, in turn, would increase the state-level Earned Income Tax Credits, reducing inequality. As immigration policy is a federal government issue, however, state-level efforts to address rising inequality by immigrants through the tax might face limitations. In the long term, states can make changes to their policy on human-capital investment that can raise middle-class incomes and reduce inequality (Heinrich and Smeedling, 2014). Better access to education and health service and well-targeted social policies can help rise the income share for the poor and the middle income group. No one-size-fits-all policy exists to tackling inequality issues, however.

Since some of the literature supports a positive effect of inequality on growth, some degree of inequality may not prove beneficial. For instance, returns to education and differentiation in labour earnings can motivate human capital accumulation and economic growth, despite its association with higher income inequality (Lazear and Rosen, 1981). Rising inequality, however, can result in large social cost, as income inequality can significantly undermine individual's educational and occupational choices. Further, a possibility exists that income inequality does not generate the "right" incentives if it rests on rents (Stiglitz, 2012). In that case, individuals have an incentive to divert their efforts toward protection, such as resource misallocation and corruption. Thus, the appropriate policies depend on the underlying drivers and state-specific policy and institutional settings.

\section{Reference}

Alesina, A., \& Perotti, R. (1996). Income distribution, political instability, and investment. European Economic Review, 40(6), 1203-1228.

Alesina, A., \& Rodrik, D. (1994). Distributive politics and economic growth. The Quarterly Journal of Economics, 109(2), 465-490.

Baltagi, B.H. (2008). Econometrics.4th Edition, Springer-Verlag Berlin Heidelberg.

Barro, R. J. (2000). Inequality and Growth in a Panel of Countries. Journal of Economic Growth, 5(1), 5-32. 
Berg, A., Ostry, J. D., \& Zettelmeyer, J. (2012). What makes growth sustained?. Journal of Development Economics, 98(2), 149-166.

Birdsall, N., Ross, D., \& Sabot, R. (1995). Inequality and growth reconsidered: lessons from East Asia. The World Bank Economic Review, 9(3), 477-508.

Bourguignon, F. (1981). Pareto superiority of unegalitarian equilibria in Stiglitz' model of wealth distribution with convex saving function. Econometrica, 1469-1475.

Breitung, J. 2005. A parametic approach to the estimation of cointegration vectors in panel data. Econometric Reviews, 24:151-173.

Breusch, T.S., and Pagan, A. R. 1980. The Lagrange Multiplier test and its applications to model specification in econometrics. The Review of Economic Studies, 47(1):239-253.

Clarke, G. R. (1995). More evidence on income distribution and growth. Journal of Development Economics, 47(2), 403-427.

Deininger, K., \& Squire, L. (1996). A new data set measuring income inequality. The World Bank Economic Review, 10(3), 565-591.

Dew-Becker, I., \& Gordon, R. J. (2005). Where did the productivity growth go? Inflation dynamics and the distribution of income (No. w11842). National Bureau of Economic Research.

Dollar, D., \& Kraay, A. (2002). Growth is Good for the Poor. Journal of Economic Growth, 7(3), 195-225.

Dougherty, S. M. The Effect of Career and Technical Education on Human Capital Accumulation: Causal Evidence from Massachusetts.

Easterly, W. (2007). Inequality does cause underdevelopment: Insights from a new instrument. Journal of Development Economics, 84(2), 755-776.

Emirmahmutoglu, F. and N. Kose. 2011. Testing for Granger causality in heterogeneous mixed panels. Economic Modelling 28: 870-876.

Fisher, R. A. (1932). Statistical methods for research workers. Edinburgh: Oliver and Boyd, 1925. Fisher Statistical Methods for Research Workers1925.

Goldin, C., \& Margo, R. A. (1992). The Great Compression: The Wage Structure in the United States at Mid-Century. The Quarterly Journal of Economics, 107(1), 1-34.

Gordon, R. J. (2009). Has the Rise in American Inequality Been Exaggerated?. Challenge, 52(3), 92-120.

Granger, C.W.J. 2003. Some aspects of causal relationships. Journal of Econometrics, 112:69-71. 
Hassler, J., \& Mora, J. V. R. (2000). Intelligence, social mobility, and growth. American Economic Review, 888-908.

Heinrich, C., \& Smeeding, T. (2014). Building human capital and economic potential. Fast Focus, (21).

Kaldor, N. (1955). Alternative theories of distribution. The Review of Economic Studies, 83100.

Krugman, P., 2007. The Conscience of a Liberal. W.W. Norton \& Company, New York, 124128.

Lazear, E. P., \& Rosen, S. (1981). Rank-Order Tournaments as Optimum Labor Contracts. The Journal of Political Economy, 89(5), 841-864.

Leigh, A. (2007). How closely do top income shares track other measures of inequality?. The Economic Journal, 117(524), F619-F633.

Morrill, R. (2000). Geographic variation in change in income inequality among US states, 1970-1990. The Annals of Regional Science, 34(1), 109-130.

Parker, J. A., \& Vissing-Jorgensen, A. (2009). Who bears aggregate fluctuations and how? (No. w14665). National Bureau of Economic Research.

Partridge, J. S., Partridge, M. D., \& Rickman, D. S. (1998). State patterns in family income inequality. Contemporary Economic Policy, 16(3), 277-294.

Partridge, M. D., Rickman, D. S., \& Levernier, W. (1996). Trends in US income inequality: evidence from a panel of states. The Quarterly Review of Economics and Finance, 36(1), 17-37.

Piketty, T., \& Saez, E. (2001). Income Inequality in the United States, 1913-1998 (series updated to 2000 available) (No. w8467). National Bureau of Economic Research.

Persson, T., \& Tabellini, G. (1992). Growth, distribution and politics. European Economic Review, 36(2), 593-602.

Pesaran, M.H. 2006. Estimation and Inference in Large Heterogeneous Panels with Multifactor Error Structure. Econometrica 74 (4): 967-1012.

Pesaran, M.H. (2004). General diagnostic tests for cross section dependence in panels. CESifo Working Papers No.1233, 255-60.

Pesaran, M.H., Ullah, A. and Yamagata, T. 2008. A bias-adjusted LM test of error crosssection independence. Econometrics Journal 11:105-127.

Saint-Paul, G., \& Verdier, T. (1993). Education, democracy and growth. Journal of Development Economics, 42(2), 399-407. 
Pesaran, M.H., Yamagata, T. 2008. Testing slope homogeneity in large panels. Journal of Econometrics 142:50-93.

Saint-Paul, G., \& Verdier, T. (1993). Education, democracy and growth. Journal of Development Economics, 42(2), 399-407.

Stiglitz, J. E. (2012). The Price of Inequality: How Today's Divided Society Endangers Our Future. WW Norton \& Company.

Swamy, P.A.V.B. 1970. Efficient inference in a random coefficient regression model. Econometrica 38:311-323.

Toda, H. Y., \& Yamamoto, T. (1995). Statistical inference in vector autoregressions with possibly integrated processes. Journal of Econometrics, 66(1), 225-250.

Wilkinson, R. G., \& Pickett, K. E. (2007). The problems of relative deprivation: why some societies do better than others. Social Science \& Medicine, 65(9), 1965-1978. 
Table 1. Cross-sectional Dependence and Homogeneity Tests (Inequality and Income)

\begin{tabular}{lcccccc}
\hline & Atkin05 & Gini & Rmeandev & Theil & Top 10\% & Top $1 \%$ \\
\hline$C D_{B P}$ & $42343.951 * * *$ & $34514.356 * * *$ & $29210.937 * * *$ & $28955.723 * * *$ & $42343.951 * * *$ & $45076.726 * * *$ \\
$C D_{L M}$ & $867.752 * * *$ & $702.910^{* * *}$ & $591.252 * * *$ & $585.879 * * *$ & $867.752 * * *$ & $925.288^{* * *}$ \\
$C D$ & $202.945^{* * *}$ & $181.227 * * *$ & $163.112 * * *$ & $163.445 * * *$ & $202.945 * * *$ & $208.543 * * *$ \\
$L M_{a d j}$ & $1708.916 * * *$ & $1735.807 * * *$ & $1656.264 * * *$ & $1569.867 * * *$ & $1583.094 * * *$ & $1600.792 * * *$ \\
$\tilde{\Delta}$ & $178.457 * * *$ & $168.938^{* * *}$ & $189.290 * * *$ & $106.396 * * *$ & $73.039 * * *$ & $100.942 * * *$ \\
$\tilde{\Delta}_{a d j}$ & $2.188^{* * *}$ & $2.072 * * *$ & $2.321 * * *$ & $1.304 *$ & 0.895 & $1.237 *$ \\
Swamy Shat & $1796.522 * * *$ & $1703.247 * * *$ & 1902.657 & $1090.463 * * *$ & $763.639 * * *$ & $1037.030 * * *$ \\
\hline \hline
\end{tabular}

Note: $1 . * * * * *$, and * indicate significance at the $0.01,0.05$, and 0.1 levels, respectively. 
Table 2. Results of Granger causality between Personal Income and Atkinson Index

\begin{tabular}{|c|c|c|c|c|c|c|c|c|c|c|c|c|c|}
\hline \multirow[t]{2}{*}{ State } & \multirow{2}{*}{$\begin{array}{l}\text { Lag } \\
\text { length }\end{array}$} & \multicolumn{6}{|c|}{$\begin{array}{c}\text { Income led hypothesis } \\
\text { H0: Income sorted does not } \\
\text { Granger Cause Atkinson Index }\end{array}$} & \multicolumn{6}{|c|}{$\begin{array}{c}\text { Inequality led hypothesis } \\
\text { H0: Atkinson Index does not } \\
\text { Granger Cause Income sorted }\end{array}$} \\
\hline & & $\begin{array}{c}\text { AIC, } \\
d \max =1\end{array}$ & & $\begin{array}{c}\text { SBC, } \\
d \max =1\end{array}$ & & $\begin{array}{c}\mathrm{AIC}, \\
\mathrm{dmax}=2\end{array}$ & & $\begin{array}{c}\mathrm{AIC}, \\
\mathrm{dmax}=1\end{array}$ & & $\begin{array}{c}\mathrm{SBC}, \\
\mathrm{dmax}=1\end{array}$ & & $\begin{array}{c}\mathrm{AIC}, \\
\mathrm{dmax}=2\end{array}$ & \\
\hline Alabama & 8 & 25.243 & $* * *$ & 26.764 & **** & 16.262 & $* *$ & 12.778 & & 16.581 & **** & 9.122 & \\
\hline Arizona & 5 & 6.528 & & 6.528 & & 5.55 & & 22.237 & $* * *$ & 22.237 & $* * *$ & 23.579 & $* * *$ \\
\hline Arkansas & 8 & 37.695 & $* * *$ & 7.663 & $* *$ & 30.128 & $* * *$ & 14.198 & $*$ & 7.196 & $* *$ & 14.125 & $*$ \\
\hline California & 8 & 27.116 & $* * *$ & 10.139 & $*$ & 23.986 & $* * *$ & 23.346 & $* * *$ & 24.117 & $* * *$ & 27.374 & $* * *$ \\
\hline Colorado & 8 & 19.89 & $* *$ & 7.427 & & 17.301 & $* *$ & 28.372 & $* * *$ & 25.05 & $* * *$ & 22.622 & $* * *$ \\
\hline Connecticut & 8 & 15.266 & $*$ & 3.236 & & 11.833 & & 26 & $* * *$ & 1.031 & & 24.24 & $* * *$ \\
\hline Delaware & 8 & 23.568 & $* * *$ & 23.568 & $* * *$ & 20.911 & $* * *$ & 24.067 & $* * *$ & 24.067 & $* * *$ & 33.252 & $* * *$ \\
\hline Florida & 8 & 8.477 & & 4.639 & & 11.371 & & 34.657 & $* * *$ & 34.386 & $* * *$ & 32.549 & $* * *$ \\
\hline Georgia & 8 & 19.321 & $* *$ & 27.941 & $* * *$ & 12.241 & & 15.135 & $*$ & 16.351 & $* * *$ & 13.013 & \\
\hline Idaho & 7 & 15.137 & $* *$ & 15.137 & $* *$ & 20.856 & $* * *$ & 13.499 & $*$ & 13.499 & $*$ & 15.404 & $* *$ \\
\hline Illinois & 8 & 17.215 & $* *$ & 16.62 & $* *$ & 8.689 & & 39.786 & $* * *$ & 18.825 & $* * *$ & 16.121 & $* *$ \\
\hline Indiana & 7 & 14.512 & $* *$ & 10.298 & $*$ & 14.711 & $* *$ & 21.553 & $* * *$ & 20.149 & $* * *$ & 22.656 & $* * *$ \\
\hline Iowa & 8 & 18.628 & $* *$ & 9.075 & & 11.481 & & 14.893 & $*$ & 11.82 & $*$ & 10.521 & \\
\hline Kansas & 8 & 27.39 & $* * *$ & 8.618 & $*$ & 22.049 & $* * *$ & 15.191 & $*$ & 14.026 & $* * *$ & 17.118 & $* *$ \\
\hline Kentucky & 7 & 13.669 & $*$ & 13.669 & $*$ & 9.226 & & 31.324 & $* * *$ & 31.324 & $* * *$ & 33.187 & $* * *$ \\
\hline Louisiana & 8 & 25.906 & $* * *$ & 25.906 & $* * *$ & 20.825 & $* * *$ & 68.666 & $* * *$ & 68.666 & $* * *$ & 55.252 & $* * *$ \\
\hline Maine & 8 & 26.861 & $* * *$ & 18.057 & $* * *$ & 15.615 & $* *$ & 25.112 & $* * *$ & 8.675 & $*$ & 24.205 & $* * *$ \\
\hline Maryland & 7 & 9.416 & & 1.279 & & 8.296 & & 13.485 & $*$ & 16.189 & $* * *$ & 9.895 & \\
\hline Massachusetts & 8 & 15.779 & $* *$ & 9.284 & $*$ & 9.363 & & 25.205 & $* * *$ & 15.596 & $* * *$ & 16.121 & $* *$ \\
\hline Michigan & 7 & 21.779 & $* * *$ & 21.779 & $* * *$ & 20.834 & $* * *$ & 16.496 & $* *$ & 16.496 & $* *$ & 13.123 & $*$ \\
\hline Minnesota & 8 & 22.488 & $* * *$ & 6.961 & & 19.037 & $* *$ & 32.389 & $* * *$ & 35.564 & $* * *$ & 27.528 & $* * *$ \\
\hline Mississippi & 8 & 28.768 & $* * *$ & 6.793 & & 13.947 & $*$ & 20.589 & $* * *$ & 14.99 & $* *$ & 15.462 & $*$ \\
\hline Missouri & 5 & 4.49 & & 4.49 & & 4.792 & & 29.07 & $* * *$ & 29.07 & $* * *$ & 24.523 & $* * *$ \\
\hline Montana & 8 & 22.544 & $* * *$ & 9.095 & $* * *$ & 18.146 & $* *$ & 18.376 & $* *$ & 0.143 & & 15.233 & $*$ \\
\hline Nebraska & 8 & 25.576 & $* * *$ & 3.62 & $*$ & 19.23 & $* *$ & 13.819 & $*$ & 0.077 & & 11.274 & \\
\hline Nevada & 8 & 12.658 & & 0.704 & & 15.767 & $* *$ & 25.026 & $* * *$ & 0.116 & & 27.156 & $* * *$ \\
\hline N. Hampshire & 8 & 9.119 & & 2.469 & & 8.477 & & 17.807 & $* *$ & 16.075 & $* * *$ & 9.797 & \\
\hline New Jersey & 8 & 29.883 & $* * *$ & 1.277 & & 19.935 & $* *$ & 25.051 & $* * *$ & 1.099 & & 15.531 & $*$ \\
\hline New Mexico & 7 & 24.556 & $* * *$ & 14.876 & $* * *$ & 27.617 & $* * *$ & 9.042 & & 7.024 & & 11.722 & \\
\hline New York & 8 & 24.731 & $* * *$ & 14.514 & $* *$ & 13.476 & $*$ & 18.166 & $* *$ & 15.847 & $* * *$ & 10.262 & \\
\hline North Carolina & 7 & 34.874 & $* * *$ & 26.277 & $* * *$ & 36.815 & $* * *$ & 8.911 & & 14.632 & $* *$ & 7.357 & \\
\hline North Dakota & 3 & 7.647 & $*$ & 5.484 & $* *$ & 8.86 & $* *$ & 1.939 & & 2.672 & & 2.612 & \\
\hline Ohio & 6 & 8.631 & & 9.71 & $*$ & 7.847 & & 19.974 & $* * *$ & 19.883 & $* * *$ & 11.476 & $*$ \\
\hline Oklahoma & 8 & 13.681 & $*$ & 4.459 & & 19.044 & $* *$ & 53.313 & $* * *$ & 13.453 & $* * *$ & 38.353 & $* * *$ \\
\hline Oregon & 8 & 22.257 & $* * *$ & 23.711 & $* * *$ & 14.618 & $*$ & 16.886 & $* *$ & 12.787 & $* *$ & 16.204 & $* *$ \\
\hline Pennsylvania & 8 & 27.514 & $* * *$ & 9.639 & $*$ & 15.984 & $* *$ & 24.827 & $* * *$ & 25.649 & $* * *$ & 14.635 & $*$ \\
\hline Rhode Island & 8 & 21.403 & $* * *$ & 0.851 & & 25.862 & $* * *$ & 29.094 & $* * *$ & 0.428 & & 25.027 & $* * *$ \\
\hline South Carolina & 8 & 19.82 & $* *$ & 11.37 & $* *$ & 9.879 & & 21.9 & $* * *$ & 22.958 & $* * *$ & 18.047 & $* *$ \\
\hline South Dakota & 8 & 18.99 & $* *$ & 20.228 & $* * *$ & 16.508 & $* *$ & 13.829 & $*$ & 11.351 & & 13.566 & $*$ \\
\hline Tennessee & 8 & 10.567 & & 15.4 & $* * *$ & 5.952 & & 32.855 & $* * *$ & 28.916 & $* * *$ & 18.181 & $* *$ \\
\hline Texas & 7 & 14.116 & $* *$ & 1.445 & & 9.594 & & 19.126 & $* * *$ & 15.481 & $* * *$ & 18.662 & $* * *$ \\
\hline Utah & 8 & 31.591 & $* * *$ & 31.591 & $* * *$ & 14.81 & $*$ & 31.403 & $* * *$ & 31.403 & $* * *$ & 39.529 & $* * *$ \\
\hline Vermont & 8 & 27.173 & $* * *$ & 2.639 & & 21.117 & $* * *$ & 19.313 & $* *$ & 0.033 & & 15.121 & $*$ \\
\hline Virginia & 8 & 29.202 & $* * *$ & 15.693 & $* * *$ & 30.481 & $* * *$ & 35.329 & $* * *$ & 23.939 & $* * *$ & 44.449 & $* * *$ \\
\hline Washington & 8 & 15.371 & $*$ & 6.278 & & 8.104 & & 25.357 & $* * *$ & 26.354 & $* * *$ & 23.325 & $* * *$ \\
\hline West Virginia & 7 & 16.507 & $* *$ & 17.826 & $* * *$ & 13.157 & $*$ & 22.013 & $* * *$ & 17.089 & $* * *$ & 12.96 & $*$ \\
\hline Wisconsin & 8 & 16.69 & $* *$ & 8.075 & & 8.056 & & 21.937 & $* * *$ & 21.205 & $* * *$ & 10.718 & \\
\hline Wyoming & 6 & 4.027 & & 6.261 & & 4.044 & & 3.275 & & 2.108 & & 3.407 & \\
\hline $\begin{array}{l}\text { Fisher test } \\
\text { statistic value }\end{array}$ & & 460.96 & & & & & & 592.007 & & & & & \\
\hline $\mathrm{AIC} \operatorname{dmax}=1$ & & CV $1 \%$ & & CV $5 \%$ & & CV10\% & & CV $1 \%$ & & CV 5\% & & CV $10 \%$ & \\
\hline & & 220.318 & & 176.509 & & 157.391 & & 217.998 & & 174.965 & & 155.848 & \\
\hline $\begin{array}{l}\text { Fisher test } \\
\text { statistic value }\end{array}$ & & 339.978 & & & & & & 544.594 & & & & & \\
\hline $\mathrm{SBC} d \max =1$ & & CV $1 \%$ & & CV 5\% & & CV10\% & & CV $1 \%$ & & CV 5\% & & CV $10 \%$ & \\
\hline & & 190.624 & & 156.549 & & 141.928 & & 194.822 & & 163.103 & & 145.22 & \\
\hline $\begin{array}{l}\text { Fisher test } \\
\text { statistic value }\end{array}$ & & 327.115 & & & & & & 473.219 & & & & & \\
\hline AIC dmax $=2$ & & CV $1 \%$ & & CV 5\% & & CV10\% & & CV $1 \%$ & & CV 5\% & & CV $10 \%$ & \\
\hline & & 193.25 & & 160.971 & & 147.621 & & 192.065 & & 162.099 & & 147.444 & \\
\hline
\end{tabular}

Note: $1 . * * *, * *$, and $*$ indicate significance at the $0.01,0.05$ and 0.1 levels, respectively.

2. Bootstrap critical values are obtained from 10,000 replications.

3. The number of appropriate lag orders in level VAR systems are selected by minimizing the Schwarz Baysian criteria. Lag order 8 is used for all states. 
Table 3. Results of Granger causality between Personal Income and Gini Coefficient

\begin{tabular}{|c|c|c|c|c|c|c|c|c|c|c|c|c|c|}
\hline \multirow[t]{2}{*}{ State } & \multirow{2}{*}{$\begin{array}{l}\text { Lag } \\
\text { length }\end{array}$} & \multicolumn{6}{|c|}{$\begin{array}{c}\text { Income led hypothesis } \\
\text { H0: Income sorted does not } \\
\text { Granger Cause Gini Coefficient }\end{array}$} & \multicolumn{6}{|c|}{$\begin{array}{c}\text { Inequality led hypothesis } \\
\text { H0: Gini Coefficient does not } \\
\text { Granger Cause Income sorted }\end{array}$} \\
\hline & & $\begin{array}{c}\mathrm{AIC}, \\
\mathrm{dmax}=1\end{array}$ & & $\begin{array}{c}\mathrm{SBC}, \\
\mathrm{dmax}=1\end{array}$ & & $\begin{array}{c}\mathrm{AIC}, \\
\mathrm{dmax}=2\end{array}$ & & $\begin{array}{c}\text { AIC, } \\
\mathrm{dmax}=1\end{array}$ & & $\begin{array}{c}\mathrm{SBC}, \\
\mathrm{dmax}=1\end{array}$ & & $\begin{array}{c}\text { AIC, } \\
d \max =2\end{array}$ & \\
\hline Alabama & 8 & 19.887 & ** & 17.559 & *** & 22.351 & $* * *$ & 22.256 & **** & 13.508 & * & 19.545 & $* *$ \\
\hline Arizona & 7 & 10.473 & & 10.282 & $* *$ & 9.076 & & 27.38 & $* * *$ & 18.692 & $* * *$ & 24.208 & $* * *$ \\
\hline Arkansas & 5 & 7.233 & & 6.858 & & 5.596 & & 11.678 & $* *$ & 11.801 & $* *$ & 10.328 & $*$ \\
\hline California & 8 & 22.147 & $* * *$ & 22.147 & $* * *$ & 22.624 & $* * *$ & 32.812 & $* * *$ & 32.812 & $* * *$ & 35.881 & $* * *$ \\
\hline Colorado & 8 & 10.196 & & 10.196 & & 11.024 & & 55.989 & $* * *$ & 55.989 & $* * *$ & 46.064 & $* * *$ \\
\hline Connecticut & 8 & 15.452 & $*$ & 15.452 & $*$ & 16.522 & $* *$ & 39.298 & $* * *$ & 39.298 & $* * *$ & 33.853 & $* * *$ \\
\hline Delaware & 8 & 32.253 & $* * *$ & 32.253 & $* * *$ & 29.065 & $* * *$ & 29.988 & $* * *$ & 29.988 & $* * *$ & 48.714 & $* * *$ \\
\hline Florida & 8 & 17.96 & $* *$ & 18.095 & $* * *$ & 7.772 & & 42.687 & $* * *$ & 31.849 & $* * *$ & 40.247 & $* * *$ \\
\hline Georgia & 8 & 14.704 & $*$ & 26.133 & $* * *$ & 11.949 & & 30.804 & $* * *$ & 25.738 & $* * *$ & 23.324 & $* * *$ \\
\hline Idaho & 8 & 25.735 & $* * *$ & 24.052 & $* * *$ & 39.289 & $* * *$ & 36.555 & $* * *$ & 27.708 & $* * *$ & 24.445 & $* * *$ \\
\hline Illinois & 8 & 26.938 & $* * *$ & 24.456 & $* * *$ & 23.009 & $* * *$ & 43.683 & $* * *$ & 12.701 & $* *$ & 18.715 & $* *$ \\
\hline Indiana & 8 & 13.929 & $*$ & 16.592 & $* *$ & 14.242 & $*$ & 31.284 & $* * *$ & 26.709 & $* * *$ & 15.142 & $*$ \\
\hline Iowa & 8 & 9.659 & & 10.183 & & 10.213 & & 18.077 & $* *$ & 19.575 & $* * *$ & 15.543 & $* *$ \\
\hline Kansas & 8 & 30.99 & $* * *$ & 21.377 & $* * *$ & 29.793 & $* * *$ & 10.668 & & 6.91 & & 11.849 & \\
\hline Kentucky & 7 & 13.531 & $*$ & 13.531 & $*$ & 10.233 & & 29.003 & $* * *$ & 29.003 & $* * *$ & 27.639 & $* * *$ \\
\hline Louisiana & 8 & 7.223 & & 7.223 & & 13.309 & & 49.444 & $* * *$ & 49.444 & $* * *$ & 39.748 & $* * *$ \\
\hline Maine & 8 & 21.894 & $* * *$ & 17.475 & $* * *$ & 15.222 & $*$ & 23.82 & $* * *$ & 3.243 & & 21.952 & $* * *$ \\
\hline Maryland & 8 & 10.677 & & 3.068 & & 10.587 & & 32.318 & $* * *$ & 22.196 & $* * *$ & 18.708 & $* *$ \\
\hline Massachusetts & 8 & 25.499 & $* * *$ & 14.45 & $* * *$ & 27.519 & $* * *$ & 31.296 & $* * *$ & 12.94 & $* *$ & 20.578 & $* * *$ \\
\hline Michigan & 7 & 20.019 & $* * *$ & 20.019 & $* * *$ & 18.064 & $* *$ & 23.333 & $* * *$ & 23.333 & $* * *$ & 19.581 & $* * *$ \\
\hline Minnesota & 8 & 23.947 & $* * *$ & 23.947 & $* * *$ & 22.838 & $* * *$ & 30.771 & $* * *$ & 30.771 & $* * *$ & 23.545 & $* * *$ \\
\hline Mississippi & 7 & 4.567 & & 3.003 & & 5.253 & & 12.434 & $*$ & 16.857 & $* *$ & 10.653 & \\
\hline Missouri & 6 & 7.814 & & 5.031 & & 6.565 & & 30.093 & $* * *$ & 29.495 & $* * *$ & 25.475 & $* * *$ \\
\hline Montana & 8 & 7.483 & & 4.165 & $* *$ & 10.477 & & 7.974 & & 0.865 & & 7.731 & \\
\hline Nebraska & 8 & 27.569 & $* * *$ & 0.031 & & 27.134 & $* * *$ & 11.697 & & 0.124 & & 10.912 & \\
\hline Nevada & 8 & 33.182 & $* * *$ & 32.823 & $* * *$ & 31.505 & $* * *$ & 23.092 & $* * *$ & 20.313 & $* * *$ & 26.067 & $* * *$ \\
\hline N. Hampshire & 8 & 12.864 & & 1.522 & & 14.006 & $*$ & 36.156 & $* * *$ & 23.675 & $* * *$ & 25.262 & $* * *$ \\
\hline New Jersey & 8 & 29.34 & $* * *$ & 1.706 & & 25.357 & $* * *$ & 38.293 & $* * *$ & 1.74 & & 26.72 & $* * *$ \\
\hline New Mexico & 8 & 13.825 & $*$ & 9.112 & $*$ & 14.015 & $*$ & 22.624 & $* * *$ & 9.25 & $*$ & 18.665 & $* *$ \\
\hline New York & 8 & 38.057 & $* * *$ & 23.227 & $* * *$ & 34.05 & $* * *$ & 23.141 & $* * *$ & 12.155 & $* *$ & 15.091 & $*$ \\
\hline North Carolina & 7 & 12.02 & & 17.3 & $* * *$ & 15.188 & $* *$ & 8.688 & & 12.087 & $* *$ & 8.074 & \\
\hline North Dakota & 7 & 13.617 & $*$ & 5.479 & $* *$ & 11.182 & & 9.373 & & 3.958 & $* *$ & 11.883 & \\
\hline Ohio & 7 & 15.987 & $* *$ & 14.907 & $* *$ & 14.34 & $* *$ & 28.587 & $* * *$ & 21.887 & $* * *$ & 35.665 & $* * *$ \\
\hline Oklahoma & 8 & 12.962 & & 2.988 & & 15.727 & $* *$ & 26.494 & $* * *$ & 15.802 & $* * *$ & 15.483 & $*$ \\
\hline Oregon & 8 & 25.954 & $* * *$ & 29.587 & $* * *$ & 28.088 & $* * *$ & 15.414 & $*$ & 32.636 & $* * *$ & 16.437 & $* *$ \\
\hline Pennsylvania & 8 & 22.906 & $* * *$ & 19.1 & $* * *$ & 22.825 & $* * *$ & 26.292 & $* * *$ & 19.752 & $* * *$ & 16.124 & $* *$ \\
\hline Rhode Island & 8 & 23.26 & $* * *$ & 0.285 & & 24.934 & $* * *$ & 46.823 & $* * *$ & 0.018 & & 37.505 & $* * *$ \\
\hline South Carolina & 8 & 5.384 & & 2.539 & & 7.358 & & 20.272 & $* * *$ & 15.253 & $* * *$ & 21.077 & $* * *$ \\
\hline South Dakota & 8 & 22.612 & $* * *$ & 23.157 & $* * *$ & 23.249 & $* * *$ & 11.926 & & 12.378 & $*$ & 8.772 & \\
\hline Tennessee & 8 & 13.75 & $*$ & 19.254 & $* * *$ & 14.084 & $*$ & 24.44 & $* * *$ & 19.887 & $* * *$ & 11.48 & \\
\hline Texas & 7 & 9.824 & & 9.824 & & 6.037 & & 13.694 & $*$ & 13.694 & $*$ & 12.533 & $*$ \\
\hline Utah & 8 & 48.434 & $* * *$ & 34.767 & $* * *$ & 33.875 & $* * *$ & 38.466 & $* * *$ & 26.511 & $* * *$ & 39.858 & $* * *$ \\
\hline Vermont & 8 & 16.903 & $* *$ & 9.453 & $*$ & 17.442 & $* *$ & 25.032 & $* * *$ & 12.377 & $* *$ & 17.925 & $* *$ \\
\hline Virginia & 8 & 16.962 & $* *$ & 14.577 & $* *$ & 16.99 & $* *$ & 55.66 & $* * *$ & 36.194 & $* * *$ & 43.315 & $* * *$ \\
\hline Washington & 8 & 19.015 & $* *$ & 13.797 & $* *$ & 19.705 & $* *$ & 18.105 & $* *$ & 19.295 & $* * *$ & 14.616 & $*$ \\
\hline West Virginia & 7 & 13.35 & $*$ & 17.523 & $* * *$ & 6.929 & & 19.205 & $* * *$ & 17.19 & $* * *$ & 13.024 & $*$ \\
\hline Wisconsin & 8 & 5.435 & & 6.18 & & 8.418 & & 22.367 & $* * *$ & 25.542 & $* * *$ & 10.575 & \\
\hline Wyoming & 4 & 2.139 & & 2.139 & & 2.139 & & 2.045 & & 2.045 & & 2.557 & \\
\hline $\begin{array}{l}\text { Fisher test } \\
\text { statistic value }\end{array}$ & & 405.633 & & & & & & 724.19 & & & & & \\
\hline $\mathrm{AIC} d \max =1$ & & $\mathrm{CV} 1 \%$ & & CV 5\% & & CV10\% & & CV $1 \%$ & & CV 5\% & & CV $10 \%$ & \\
\hline & & 225.97 & & 180.168 & & 159.523 & & 224.271 & & 182.758 & & 161.691 & \\
\hline $\begin{array}{l}\text { Fisher test } \\
\text { statistic value }\end{array}$ & & 403.825 & & & & & & 609.102 & & & & & \\
\hline $\mathrm{SBC}$ dmax $=1$ & & CV $1 \%$ & & CV 5\% & & CV $10 \%$ & & CV $1 \%$ & & CV 5\% & & CV $10 \%$ & \\
\hline & & 193.456 & & 160.408 & & 144.1 & & 198.094 & & 163.79 & & 148.543 & \\
\hline $\begin{array}{l}\text { Fisher test } \\
\text { statistic value }\end{array}$ & & 382.65 & & & & & & 546.644 & & & & & \\
\hline $\mathrm{AIC} d \max =2$ & & CV 1\% & & CV 5\% & & CV $10 \%$ & & CV $1 \%$ & & CV 5\% & & CV $10 \%$ & \\
\hline & & 205.921 & & 168.096 & & 151.267 & & 206.634 & & 170.309 & & 153.597 & \\
\hline
\end{tabular}

Note: $1 . * * *, * *$, and $*$ indicate significance at the $0.01,0.05$ and 0.1 levels, respectively.

2 . Bootstrap critical values are obtained from 10,000 replications. 
Table 4. Results of Granger causality between Personal Income and Relative Mean Deviation

\begin{tabular}{|c|c|c|c|c|c|c|c|c|c|c|c|c|c|}
\hline \multirow[t]{2}{*}{ state } & \multirow{2}{*}{$\begin{array}{l}\text { Lag } \\
\text { length }\end{array}$} & \multicolumn{6}{|c|}{$\begin{array}{c}\text { Income led hypothesis } \\
\text { H0: Income sorted does not } \\
\text { Granger Cause the Relative Mean Deviation }\end{array}$} & \multicolumn{6}{|c|}{$\begin{array}{c}\text { Inequality led hypothesis } \\
\text { H0: the Relative Mean Deviation does not } \\
\text { Granger Cause Income sorted }\end{array}$} \\
\hline & & $\begin{array}{c}\text { AIC, } \\
\mathrm{dmax}=1\end{array}$ & & $\begin{array}{c}\mathrm{SBC}, \\
\mathrm{dmax}=1\end{array}$ & & $\begin{array}{c}\text { AIC, } \\
\mathrm{dmax}=2\end{array}$ & & $\begin{array}{c}\mathrm{AIC}, \\
\mathrm{dmax}=1\end{array}$ & & $\begin{array}{c}\mathrm{SBC}, \\
\mathrm{dmax}=1\end{array}$ & & $\begin{array}{c}\text { AIC, } \\
\mathrm{dmax}=2\end{array}$ & \\
\hline Alabama & $\overline{88}$ & 28.149 & **** & 1014.627 & *** & 23.048 & $* * *$ & 24.951 & "*** & 41.917 & "*** & 19.38 & $* *$ \\
\hline Arizona & 7 & 17.213 & $* *$ & 17.213 & $* *$ & 16.157 & $* *$ & 30.047 & $* * *$ & 30.047 & $* * *$ & 25.985 & $* * *$ \\
\hline Arkansas & 8 & 15.508 & $*$ & 7.795 & & 16.975 & $* *$ & 31.824 & $* * *$ & 33.372 & $* * *$ & 31.76 & $* * *$ \\
\hline California & 8 & 30.529 & $* * *$ & 30.529 & $* * *$ & 29.334 & $* * *$ & 33.28 & $* * *$ & 33.28 & $* * *$ & 28.322 & $* * *$ \\
\hline Colorado & 8 & 15.053 & $*$ & 15.053 & $*$ & 18.418 & $* *$ & 51.176 & $* * *$ & 51.176 & $* * *$ & 40.199 & $* * *$ \\
\hline Connecticut & 8 & 19.107 & $* *$ & 19.107 & $* *$ & 21.47 & $* * *$ & 44.127 & $* * *$ & 44.127 & $* * *$ & 29.442 & $* * *$ \\
\hline Delaware & 8 & 42.638 & $* * *$ & 42.638 & $* * *$ & 46.287 & $* * *$ & 33.777 & $* * *$ & 33.777 & $* * *$ & 54.156 & $* * *$ \\
\hline Florida & 8 & 13.616 & $*$ & 13.616 & $*$ & 16.197 & $* *$ & 56.789 & $* * *$ & 56.789 & $* * *$ & 53.687 & $* * *$ \\
\hline Georgia & 8 & 14.005 & $*$ & 14.005 & $*$ & 11.296 & & 72.398 & $* * *$ & 72.398 & $* * *$ & 62.814 & $* * *$ \\
\hline Idaho & 8 & 35.665 & $* * *$ & 35.595 & $* * *$ & 50.548 & $* * *$ & 60.299 & $* * *$ & 33.387 & $* * *$ & 38.491 & $* * *$ \\
\hline Illinois & 8 & 28.096 & $* * *$ & 8.531 & & 22.72 & $* * *$ & 72.855 & $* * *$ & 28.827 & $* * *$ & 38.574 & $* * *$ \\
\hline Indiana & 8 & 32.506 & $* * *$ & 17.017 & $* *$ & 23.154 & $* * *$ & 48.274 & $* * *$ & 36.978 & $* * *$ & 21.639 & $* * *$ \\
\hline Iowa & 8 & 7.606 & & 7.606 & & 7.955 & & 23.488 & $* * *$ & 23.488 & $* * *$ & 21.596 & $* * *$ \\
\hline Kansas & 8 & 51.205 & $* * *$ & 51.205 & $* * *$ & 36.928 & $* * *$ & 21.615 & $* * *$ & 21.615 & $* * *$ & 17.971 & $* *$ \\
\hline Kentucky & 7 & 15.917 & $* *$ & 15.917 & $* *$ & 13.515 & $*$ & 51.057 & $* * *$ & 51.057 & $* * *$ & 42.928 & $* * *$ \\
\hline Louisiana & 8 & 20.228 & $* *$ & 20.228 & $* *$ & 25.578 & $* * *$ & 61.421 & $* * *$ & 61.421 & $* * *$ & 43.11 & $* * *$ \\
\hline Maine & 8 & 21.815 & $* * *$ & 16.558 & $* *$ & 22.828 & $* * *$ & 29.503 & $* * *$ & 20.784 & $* * *$ & 23.558 & $* * *$ \\
\hline Maryland & 8 & 26.154 & $* * *$ & 5.34 & & 23.852 & $* * *$ & 44.449 & $* * *$ & 23.757 & $* * *$ & 28.718 & $* * *$ \\
\hline Massachusetts & 8 & 14.103 & $*$ & 9.795 & $*$ & 17.495 & $* *$ & 46.562 & $* * *$ & 20.412 & $* * *$ & 32.301 & $* * *$ \\
\hline Michigan & 8 & 71.539 & $* * *$ & 31.564 & $* * *$ & 80.467 & $* * *$ & 58.039 & $* * *$ & 28.435 & $* * *$ & 29.076 & $* * *$ \\
\hline Minnesota & 8 & 38.335 & $* * *$ & 38.335 & $* * *$ & 36.85 & $* * *$ & 34.265 & $* * *$ & 34.265 & $* * *$ & 23.766 & $* * *$ \\
\hline Mississippi & 8 & 31.203 & $* * *$ & 13.147 & $* *$ & 31.683 & $* * *$ & 35.735 & $* * *$ & 22.961 & $* * *$ & 52.04 & $* * *$ \\
\hline Missouri & 8 & 15.018 & $*$ & 7.1 & & 14.546 & $*$ & 52.076 & $* * *$ & 44.011 & $* * *$ & 32.87 & $* * *$ \\
\hline Montana & 8 & 14.412 & $*$ & 6.791 & $* * *$ & 16.013 & $* *$ & 17.637 & $* *$ & 0.229 & & 14.897 & $*$ \\
\hline Nebraska & 8 & 28.939 & $* * *$ & 28.939 & $* * *$ & 29.36 & $* * *$ & 18.448 & $* *$ & 18.448 & $* *$ & 17.022 & $* *$ \\
\hline Nevada & 8 & 13.561 & $*$ & 13.561 & $*$ & 16.279 & $* *$ & 27.103 & $* * *$ & 27.103 & $* * *$ & 23.696 & $* * *$ \\
\hline N. Hampshire & 8 & 14.605 & $*$ & 2.376 & & 16.744 & $* *$ & 43.557 & $* * *$ & 27.62 & $* * *$ & 28.039 & $* * *$ \\
\hline New Jersey & 8 & 22.593 & $* * *$ & 5.973 & & 33.982 & $* * *$ & 70.425 & $* * *$ & 41.288 & $* * *$ & 55.034 & $* * *$ \\
\hline New Mexico & 7 & 20.056 & $* * *$ & 20.056 & $* * *$ & 16.457 & $* *$ & 37.007 & $* * *$ & 37.007 & $* * *$ & 37.344 & $* * *$ \\
\hline New York & 8 & 21.771 & $* * *$ & 6.895 & & 13.177 & & 51.467 & $* * *$ & 34.689 & $* * *$ & 38.247 & $* * *$ \\
\hline North Carolina & 8 & 23.031 & $* * *$ & 30.513 & $* * *$ & 29.145 & $* * *$ & 18.953 & $* *$ & 22.925 & $* * *$ & 33.549 & $* * *$ \\
\hline North Dakota & 8 & 18.655 & $* *$ & 6.802 & $* * *$ & 20.378 & $* * *$ & 11.417 & & 3.054 & $*$ & 9.937 & \\
\hline Ohio & 8 & 40.161 & $* * *$ & 11.247 & $* *$ & 37.793 & $* * *$ & 51.38 & $* * *$ & 25.62 & $* * *$ & 29.73 & $* * *$ \\
\hline Oklahoma & 8 & 20.784 & $* * *$ & 20.784 & $* * *$ & 18.538 & $* *$ & 53.59 & $* * *$ & 53.59 & $* * *$ & 38.283 & $* * *$ \\
\hline Oregon & 8 & 26.285 & $* * *$ & 32.143 & $* * *$ & 19.443 & $* *$ & 37.192 & $* * *$ & 56.901 & $* * *$ & 33.422 & $* * *$ \\
\hline Pennsylvania & 8 & 30.813 & $* * *$ & 30.813 & $* * *$ & 28.284 & $* * *$ & 52.64 & $* * *$ & 52.64 & $* * *$ & 26.244 & $* * *$ \\
\hline Rhode Island & 8 & 33.388 & $* * *$ & 33.388 & $* * *$ & 45.494 & $* * *$ & 43.036 & $* * *$ & 43.036 & $* * *$ & 31.824 & $* * *$ \\
\hline South Carolina & 8 & 11.754 & & 13.863 & $* *$ & 13.212 & & 36.016 & $* * *$ & 29.302 & $* * *$ & 28.211 & $* * *$ \\
\hline South Dakota & 8 & 21.891 & $* * *$ & 21.891 & $* * *$ & 24.321 & $* * *$ & 12.702 & & 12.702 & & 9.74 & \\
\hline Tennessee & 8 & 9.462 & & 16.611 & $* * *$ & 8.278 & & 68.402 & $* * *$ & 62.575 & $* * *$ & 40.406 & $* * *$ \\
\hline Texas & 7 & 8.706 & & 8.706 & & 7.386 & & 38.555 & $* * *$ & 38.555 & $* * *$ & 35.399 & $* * *$ \\
\hline Utah & 8 & 62.683 & $* * *$ & 62.683 & $* * *$ & 40.606 & $* * *$ & 30.458 & $* * *$ & 30.458 & $* * *$ & 35.671 & $* * *$ \\
\hline Vermont & 8 & 32.492 & $* * *$ & 16.112 & $* * *$ & 29.772 & $* * *$ & 35.337 & $* * *$ & 20.51 & $* * *$ & 26.145 & $* * *$ \\
\hline Virginia & 8 & 28.294 & $* * *$ & 28.294 & $* * *$ & 33.7 & $* * *$ & 99.248 & $* * *$ & 99.248 & $* * *$ & 101.589 & $* * *$ \\
\hline Washington & 8 & 16.836 & $* *$ & 9.852 & & 13.935 & $*$ & 33.563 & $* * *$ & 27.803 & $* * *$ & 30.008 & $* * *$ \\
\hline West Virginia & 8 & 27.015 & $* * *$ & 17.296 & $* * *$ & 34.261 & $* * *$ & 32.821 & $* * *$ & 24.227 & $* * *$ & 35.979 & $* * *$ \\
\hline Wisconsin & 8 & 11.667 & & 11.667 & & 14.444 & $*$ & 28.49 & $* * *$ & 28.49 & $* * *$ & 10.623 & \\
\hline Wyoming & 6 & 2.94 & & 1.602 & & 2.977 & & 11.677 & $*$ & 3.208 & & 11.566 & $*$ \\
\hline $\begin{array}{l}\text { Fisher test } \\
\text { statistic value }\end{array}$ & & 631.99 & & & & & & $\inf$ & & & & & \\
\hline $\mathrm{AIC} \operatorname{dmax}=1$ & & CV $1 \%$ & & CV 5\% & & CV10\% & & CV $1 \%$ & & CV 5\% & & CV10\% & \\
\hline & & 232.605 & & 181.288 & & 161.302 & & 253.533 & & 196.213 & & 170.298 & \\
\hline $\begin{array}{l}\text { Fisher test } \\
\text { statistic value }\end{array}$ & & 515.951 & & & & & & inf & & & & & \\
\hline $\mathrm{SBC} d \max =1$ & & $\mathrm{CV} 1 \%$ & & CV 5\% & & CV10\% & & CV $1 \%$ & & CV 5\% & & CV10\% & \\
\hline & & 203.074 & & 170.01 & & 153.255 & & 217.667 & & 175.752 & & 158.151 & \\
\hline $\begin{array}{l}\text { Fisher test } \\
\text { statistic value }\end{array}$ & & 634.493 & & & & & & $\inf$ & & & & & \\
\hline $\mathrm{AIC} d \max =2$ & & CV $1 \%$ & & CV 5\% & & CV10\% & & CV $1 \%$ & & CV 5\% & & CV $0 \%$ & \\
\hline & & 201.294 & & 166.744 & & 149.775 & & 211.049 & & 211.049 & & 153.337 & \\
\hline
\end{tabular}

Note: $1 . * * *, * *$, and $*$ indicate significance at the $0.01,0.05$ and 0.1 levels, respectively.

2 . Bootstrap critical values are obtained from 10,000 replications. 
Table 5. Results of Granger causality between Personal Income and Theil's Entropy Index

\begin{tabular}{|c|c|c|c|c|c|c|c|c|c|c|c|c|c|}
\hline \multirow[t]{2}{*}{ state } & \multirow{2}{*}{$\begin{array}{l}\text { Lag } \\
\text { length }\end{array}$} & \multicolumn{6}{|c|}{$\begin{array}{c}\text { Income led hypothesis } \\
\text { H0: Income sorted does not } \\
\text { Granger Cause Theil's entropy Index }\end{array}$} & \multicolumn{6}{|c|}{$\begin{array}{c}\text { Inequality led hypothesis } \\
\text { H0: Theil's entropy Index does not } \\
\text { Granger Cause Income sorted }\end{array}$} \\
\hline & & $\begin{array}{c}\text { AIC, } \\
\mathrm{dmax}=1\end{array}$ & & $\begin{array}{c}\mathrm{SBC}, \\
\mathrm{dmax}=1\end{array}$ & & $\begin{array}{c}\text { AIC, } \\
\mathrm{dmax}=2\end{array}$ & & $\begin{array}{c}\text { AIC, } \\
\mathrm{dmax}=1\end{array}$ & & $\begin{array}{c}\mathrm{SBC}, \\
\mathrm{dmax}=1\end{array}$ & & $\begin{array}{c}\text { AIC, } \\
\mathrm{dmax}=2\end{array}$ & \\
\hline Alabama & 8 & 8.645 & & 9.458 & $*$ & 8.762 & & 6.806 & & 1010.801 & $*$ & 5.293 & \\
\hline Arizona & 6 & 5.656 & & 7.794 & & 4.92 & & 19.333 & $* * *$ & 14.939 & $* *$ & 16.692 & $* *$ \\
\hline Arkansas & 8 & 15.441 & $*$ & 1.086 & & 13.206 & & 9.604 & & 0.944 & & 5.116 & \\
\hline California & 5 & 10.725 & $*$ & 13.195 & $* *$ & 10.115 & $*$ & 15.797 & $* * *$ & 15.744 & $* * *$ & 14.322 & $* *$ \\
\hline Colorado & 8 & 12.999 & & 8.054 & & 13.068 & & 24.829 & $* * *$ & 19.237 & $* * *$ & 24.384 & $* * *$ \\
\hline Connecticut & 8 & 9.282 & & 2.635 & & 7.067 & & 27.099 & $* * *$ & 0.923 & & 31.57 & $* * *$ \\
\hline Delaware & 8 & 27.436 & $* * *$ & 27.436 & $* * *$ & 21.024 & $* * *$ & 16.415 & $* *$ & 16.415 & $* *$ & 18.619 & $* *$ \\
\hline Florida & 8 & 6.624 & & 4.064 & & 7.144 & & 27.708 & $* * *$ & 32.26 & $* * *$ & 27.291 & $* * *$ \\
\hline Georgia & 8 & 15.36 & $*$ & 17.382 & $* * *$ & 14.269 & $*$ & 17.319 & $* *$ & 8.198 & & 16.457 & $* *$ \\
\hline Idaho & 7 & 6.493 & & 6.493 & & 10.823 & & 10.725 & & 10.725 & & 7.144 & \\
\hline Illinois & 6 & 12.717 & $* *$ & 12.717 & $* *$ & 9.18 & & 18.203 & $* * *$ & 18.203 & $* * *$ & 18.859 & $* * *$ \\
\hline Indiana & 5 & 8.807 & & 8.807 & & 7.26 & & 8.878 & & 8.878 & & 3.745 & \\
\hline Iowa & 8 & 11.892 & & 5.275 & & 12.005 & & 11.604 & & 17.427 & $* * *$ & 8.113 & \\
\hline Kansas & 8 & 14.87 & $*$ & 4.409 & & 15.153 & $*$ & 11.351 & & 5.105 & & 15.803 & $* *$ \\
\hline Kentucky & 7 & 12.005 & & 10.117 & $*$ & 8.487 & & 13.932 & $*$ & 13.932 & $* *$ & 13.549 & $*$ \\
\hline Louisiana & 8 & 8.226 & & 8.226 & & 5.794 & & 28.124 & $* * *$ & 28.124 & $* * *$ & 20.184 & $* *$ \\
\hline Maine & 8 & 33.844 & $* * *$ & 23.86 & $* * *$ & 16.495 & $* *$ & 29.327 & $* * *$ & 24.89 & $* * *$ & 32.603 & $* * *$ \\
\hline Maryland & 7 & 7.085 & & 3.098 & & 6.473 & & 8.731 & & 1.877 & & 8.554 & \\
\hline Massachusetts & 8 & 9.087 & & 1.679 & & 6.5 & & 20.992 & $* * *$ & 0.776 & & 12.316 & \\
\hline Michigan & 7 & 13.755 & $*$ & 12.168 & $* *$ & 14.973 & $* *$ & 15.71 & $* *$ & 15.171 & $* *$ & 14.612 & $* *$ \\
\hline Minnesota & 7 & 9.216 & & 4.037 & & 8.829 & & 24.147 & $* * *$ & 30.052 & $* * *$ & 25.188 & $* * *$ \\
\hline Mississippi & 8 & 6.282 & & 2.939 & & 3.996 & & 9.261 & & 4.172 & & 5.358 & \\
\hline Missouri & 5 & 5.142 & & 5.142 & & 4.78 & & 16.747 & $* * *$ & 16.747 & $* * *$ & 13.538 & $* *$ \\
\hline Montana & 8 & 7.393 & & 6.053 & $* *$ & 5.279 & & 16.833 & $* *$ & 0.209 & & 15.046 & $*$ \\
\hline Nebraska & 8 & 13.751 & $*$ & 1.953 & & 12.025 & & 12.289 & & 0.562 & & 11.618 & \\
\hline Nevada & 8 & 10.561 & & 0.906 & & 12.251 & & 21.458 & $* * *$ & 0.148 & & 18.858 & $* *$ \\
\hline N. Hampshire & 8 & 7.043 & & 2.329 & & 6.619 & & 13.622 & $*$ & 13.977 & $* * *$ & 7.492 & \\
\hline New Jersey & 8 & 12.568 & & 0.972 & & 9.378 & & 17.752 & $* *$ & 0.327 & & 11.354 & \\
\hline New Mexico & 7 & 15.423 & $* *$ & 10.88 & $* *$ & 15.149 & $* *$ & 5.272 & & 3.679 & & 5.223 & \\
\hline New York & 8 & 11.66 & & 8.589 & & 6.914 & & 13.075 & & 10.402 & $*$ & 7.232 & \\
\hline N. Carolina & 7 & 21.734 & $* * *$ & 14.201 & $* *$ & 23.919 & $* * *$ & 4.187 & & 7.423 & & 3.401 & \\
\hline North Dakota & 5 & 7.888 & & 2.565 & & 8.237 & & 3.769 & & 4.315 & $* *$ & 3.126 & \\
\hline Ohio & 6 & 8.954 & & 7.661 & & 8.297 & & 14.779 & $* *$ & 12.868 & $* *$ & 8.254 & \\
\hline Oklahoma & 8 & 13.693 & $*$ & 1.019 & & 17.123 & $* *$ & 26.68 & $* * *$ & 5.016 & & 16.161 & $* *$ \\
\hline Oregon & 8 & 9.83 & & 5.375 & & 8.063 & & 7.078 & & 7.6 & & 7.056 & \\
\hline Pennsylvania & 5 & 8.602 & & 8.602 & & 9.113 & & 20.777 & $* * c *$ & 20.777 & $* * *$ & 16.536 & $* * *$ \\
\hline Rhode Island & 8 & 13.567 & $*$ & 0.257 & & 16.219 & $* *$ & 18.294 & $* *$ & 0.176 & & 15.348 & $*$ \\
\hline S. Carolina & 8 & 12.493 & & 3.55 & & 8.5 & & 17.745 & $* *$ & 8.181 & $*$ & 13.552 & $*$ \\
\hline South Dakota & 8 & 7.694 & & 3.906 & & 6.412 & & 7.27 & & 6.381 & & 6.353 & \\
\hline Tennessee & 5 & 8.671 & & 8.671 & & 7.208 & & 10.367 & $*$ & 10.367 & $*$ & 6.856 & \\
\hline Texas & 7 & 10.352 & & 2.869 & & 9.707 & & 18.797 & $* * *$ & 16.445 & $* * *$ & 17.291 & $* *$ \\
\hline Utah & 8 & 9.512 & & 4.523 & & 7.571 & & 24.829 & $* * *$ & 2.5 & & 32.135 & $* * *$ \\
\hline Vermont & 8 & 10.863 & & 3.792 & & 9.244 & & 12.964 & & 1.302 & & 10.313 & \\
\hline Virginia & 8 & 21.911 & $* * *$ & 9.036 & & 19.394 & $* *$ & 34.717 & $* * *$ & 31.896 & $* * *$ & 35.845 & $* * *$ \\
\hline Washington & 8 & 5.707 & & 3.303 & & 3.261 & & 25.911 & $* * *$ & 23.161 & $* * *$ & 24.473 & $* * *$ \\
\hline West Virginia & 7 & 10.983 & & 12.707 & $* *$ & 9.095 & & 10.899 & & 10.095 & $*$ & 7.086 & \\
\hline Wisconsin & 8 & 3.138 & & 3.998 & & 1.504 & & 13.782 & $*$ & 10.308 & $*$ & 7.813 & \\
\hline Wyoming & 5 & 4.489 & & 4.489 & & 6.913 & & 2.373 & & 2.373 & & 1.828 & \\
\hline $\begin{array}{l}\text { Fisher test } \\
\text { statistic value }\end{array}$ & & 202.651 & & & & & & 360.295 & & & & & \\
\hline $\mathrm{AIC} \operatorname{dmax}=1$ & & CV $1 \%$ & & CV 5\% & & CV10\% & & CV $1 \%$ & & CV 5\% & & CV $10 \%$ & \\
\hline & & 202.863 & & 166.808 & & 150.332 & & 194.826 & & 161.299 & & 146.306 & \\
\hline $\begin{array}{l}\text { Fisher test } \\
\text { statistic value }\end{array}$ & & 182.723 & & & & & & 325.608 & & & & & \\
\hline $\mathrm{SBC} d \max =1$ & & CV $1 \%$ & & CV 5\% & & CV10\% & & CV $1 \%$ & & CV 5\% & & $\mathrm{C} 10 \%$ & \\
\hline & & 181.017 & & 151.489 & & 136.852 & & 184.273 & & 152.324 & & 138.087 & \\
\hline $\begin{array}{l}\text { Fisher test } \\
\text { statistic value }\end{array}$ & & 166.494 & & & & & & 299.788 & & & & & \\
\hline $\mathrm{AIC} d \max =2$ & & CV $1 \%$ & & CV 5\% & & CV10\% & & CV $1 \%$ & & CV 5\% & & CV10\% & \\
\hline & & 195.072 & & 163.16 & & 148.601 & & 184.903 & & 155.609 & & 141.827 & \\
\hline
\end{tabular}

Note: $1 . * * *, * *$, and $*$ indicate significance at the $0.01,0.05$ and 0.1 levels, respectively.

2 . Bootstrap critical values are obtained from 10,000 replications. 
Table 6. Results of Granger causality between Personal Income and Top 10\% Income Share

\begin{tabular}{|c|c|c|c|c|c|c|c|c|c|c|c|c|c|}
\hline \multirow[t]{2}{*}{ state } & \multirow{2}{*}{$\begin{array}{l}\text { Lag } \\
\text { length }\end{array}$} & \multicolumn{6}{|c|}{$\begin{array}{l}\text { Income led hypothesis } \\
\text { H0: Income sorted does not } \\
\text { Granger Cause Top } 10\end{array}$} & \multicolumn{6}{|c|}{$\begin{array}{c}\text { Inequality led hypothesis } \\
\text { H0: Top10 does not } \\
\text { Granger Cause Income sorted }\end{array}$} \\
\hline & & $\begin{array}{c}\text { AIC, } \\
\mathrm{dmax}=1\end{array}$ & & $\begin{array}{c}\mathrm{SBC}, \\
\mathrm{dmax}=1\end{array}$ & & $\begin{array}{c}\text { AIC, } \\
\mathrm{dmax}=2\end{array}$ & & $\begin{array}{c}\text { AIC, } \\
\mathrm{dmax}=1\end{array}$ & & $\begin{array}{c}\mathrm{SBC}, \\
\mathrm{dmax}=1\end{array}$ & & $\begin{array}{c}\text { AIC, } \\
\mathrm{dmax}=2\end{array}$ & \\
\hline Alabama & 8 & 30.204 & $* * *$ & 15.645 & *** & 21.126 & $* * *$ & 1015.121 & * & 12.367 & * & 25.563 & "*** \\
\hline Arizona & 8 & 8.861 & & 8.69 & & 7.078 & & 13.279 & & 8.644 & & 10.53 & \\
\hline Arkansas & 8 & 31.152 & $* * *$ & 14.916 & $* *$ & 21.402 & $* * *$ & 24.521 & $* * *$ & 14.038 & $* *$ & 21.988 & $* * *$ \\
\hline California & 8 & 20.806 & $* * *$ & 17.368 & $* * *$ & 13.388 & $*$ & 13.976 & $*$ & 2.968 & & 14.761 & $*$ \\
\hline Colorado & 8 & 17.779 & $* *$ & 13.776 & $*$ & 11.137 & & 33.022 & $* * *$ & 26.372 & $* * *$ & 43.062 & $* * *$ \\
\hline Connecticut & 8 & 21.282 & $* * *$ & 11.865 & $* * *$ & 21.306 & $* * *$ & 23.197 & $* * *$ & 0.637 & & 32.508 & $* * *$ \\
\hline Delaware & 8 & 53.424 & $* * *$ & 53.424 & $* * *$ & 49.834 & $* * *$ & 29.735 & $* * *$ & 29.735 & $* * *$ & 34.973 & $* * *$ \\
\hline Florida & 8 & 12.773 & & 5.174 & & 9.024 & & 22.774 & $* * *$ & 21.731 & $* * *$ & 23.158 & $* * *$ \\
\hline Georgia & 8 & 18.024 & $* *$ & 5.113 & $*$ & 12.949 & & 20.107 & $* *$ & 1.759 & & 19.746 & $* *$ \\
\hline Idaho & 8 & 23.788 & $* * *$ & 9.326 & & 27.543 & $* * *$ & 18.707 & $* *$ & 7.425 & & 14.669 & $*$ \\
\hline Illinois & 8 & 35.141 & $* * *$ & 12.094 & $* *$ & 28.561 & $* * *$ & 17.119 & $* *$ & 6.489 & & 19.125 & $* *$ \\
\hline Indiana & 8 & 30.106 & $* * *$ & 10.874 & $*$ & 21.738 & $* * *$ & 24.834 & $* * *$ & 7.723 & & 31.706 & $* * *$ \\
\hline Iowa & 8 & 22.876 & $* * *$ & 19.08 & $* * *$ & 23.894 & $* * *$ & 11.155 & & 6.783 & & 18.21 & $* *$ \\
\hline Kansas & 8 & 20.696 & $* * *$ & 20.696 & $* * *$ & 21.302 & $* * *$ & 23.557 & $* * *$ & 23.557 & $* * *$ & 36.126 & $* * *$ \\
\hline Kentucky & 7 & 18.726 & $* * *$ & 8.168 & $*$ & 14.871 & $* *$ & 12.194 & $*$ & 2.809 & & 13.871 & $*$ \\
\hline Louisiana & 8 & 19.768 & $* *$ & 12.296 & $* *$ & 13.625 & $*$ & 34.085 & $* * *$ & 12.186 & $* *$ & 34.256 & $* * *$ \\
\hline Maine & 6 & 33.116 & $* * *$ & 33.116 & $* * *$ & 29.674 & $* * *$ & 17.875 & $* * *$ & 17.875 & $* * *$ & 16.539 & $* *$ \\
\hline Maryland & 6 & 11.9 & $*$ & 8.986 & $* *$ & 13.643 & $* *$ & 16.917 & $* *$ & 4.586 & & 16.9 & $* *$ \\
\hline Massachusetts & 8 & 15.354 & $*$ & 9.641 & $* * *$ & 13.152 & & 16.434 & $* *$ & 1.471 & & 19.374 & $* *$ \\
\hline Michigan & 8 & 29.351 & $* * *$ & 9.833 & $*$ & 21.725 & $* * *$ & 23.037 & $* * *$ & 8.879 & & 24.068 & $* * *$ \\
\hline Minnesota & 8 & 18.839 & $* *$ & 3.288 & $*$ & 18.59 & $* *$ & 8.761 & & 2.746 & $*$ & 11.219 & \\
\hline Mississippi & 8 & 18.581 & $* *$ & 12.311 & $* *$ & 12.733 & & 27.259 & $* * *$ & 10.583 & $*$ & 30.474 & $* * *$ \\
\hline Missouri & 8 & 28.813 & $* * *$ & 14.091 & $* * *$ & 26.55 & $* * *$ & 21.61 & $* * *$ & 8.342 & $*$ & 16.216 & $* *$ \\
\hline Montana & 8 & 18.499 & $* *$ & 3.69 & & 15.133 & $*$ & 8.858 & & 0.1 & & 6.829 & \\
\hline Nebraska & 8 & 14.708 & $*$ & 4.972 & $* *$ & 11.613 & & 21.622 & $* * *$ & 3.072 & $*$ & 28.692 & $* * *$ \\
\hline Nevada & 8 & 28.686 & $* * *$ & 0.602 & & 31.354 & $* * *$ & 40.408 & $* * *$ & 0.138 & & 43.527 & $* * *$ \\
\hline N. Hampshire & 8 & 15.011 & $*$ & 5.581 & & 14.272 & $*$ & 12.459 & & 4.621 & & 13.708 & $*$ \\
\hline New Jersey & 8 & 19.817 & $* *$ & 4.488 & & 16.76 & $* *$ & 14.901 & $*$ & 1.269 & & 20.436 & $* * *$ \\
\hline New Mexico & 8 & 38.304 & $* * *$ & 20.027 & $* * *$ & 18.634 & $* *$ & 26.916 & $* * *$ & 6.896 & & 22.503 & $* * *$ \\
\hline New York & 8 & 13.233 & & 1.446 & & 10.458 & & 23.244 & $* * *$ & 12.578 & $* *$ & 30.074 & $* * *$ \\
\hline North Carolina & 8 & 25.813 & $* * *$ & 14.553 & $* *$ & 20.285 & $* * *$ & 21.171 & $* * *$ & 18.847 & $* * *$ & 22.958 & $* * *$ \\
\hline North Dakota & 8 & 12.288 & & 6.337 & $*$ & 9.758 & & 18.522 & $* *$ & 12.061 & $* * *$ & 20.451 & $* * *$ \\
\hline Ohio & 8 & 22.118 & $* * *$ & 5.293 & & 16.818 & $* *$ & 23.57 & $* * *$ & 4.728 & & 26.181 & $* * *$ \\
\hline Oklahoma & 8 & 21.455 & $* * *$ & 7.606 & & 16.414 & $* *$ & 42.613 & $* * *$ & 8.8 & $*$ & 35.26 & $* * *$ \\
\hline Oregon & 8 & 26.54 & $* * *$ & 15.57 & $* *$ & 19.833 & $* *$ & 21.537 & $* * *$ & 9.523 & & 25.192 & $* * *$ \\
\hline Pennsylvania & 8 & 16.892 & $* *$ & 14.372 & $* *$ & 14.697 & $*$ & 19.805 & $* *$ & 13.136 & $* *$ & 17.658 & $* *$ \\
\hline Rhode Island & 8 & 26.306 & $* * *$ & 12.154 & $* * *$ & 25.566 & $* * *$ & 17.419 & $* *$ & 0.557 & & 28.954 & $* * *$ \\
\hline South Carolina & 8 & 26.772 & $* * *$ & 16.123 & $* *$ & 18.945 & $* *$ & 42.875 & $* * *$ & 27.277 & $* * *$ & 47.694 & $* * *$ \\
\hline South Dakota & 8 & 14.198 & $*$ & 6.339 & & 15.308 & $*$ & 12.496 & & 5.708 & & 10.972 & \\
\hline Tennessee & 8 & 21.624 & $* * *$ & 8.022 & & 16.768 & $* *$ & 21.614 & $* * *$ & 9.857 & $*$ & 30.508 & $* * *$ \\
\hline Texas & 7 & 11.717 & & 13.982 & $* * *$ & 13.078 & $*$ & 11.722 & & 1.544 & & 13.49 & $*$ \\
\hline Utah & 8 & 10.991 & & 5.419 & & 6.846 & & 26.146 & $* * *$ & 2.883 & & 30.387 & $* * *$ \\
\hline Vermont & 8 & 14.959 & $*$ & 1.484 & & 15.925 & $* *$ & 13.765 & $*$ & 0.932 & & 19.048 & $* *$ \\
\hline Virginia & 8 & 31.989 & $* * *$ & 15.596 & $* * *$ & 28.673 & $* * *$ & 33.88 & $* * *$ & 0.994 & & 32.422 & $* * *$ \\
\hline Washington & 8 & 20.113 & $* *$ & 10.904 & $*$ & 19.457 & $* *$ & 30.157 & $* * *$ & 15.208 & $* *$ & 28.589 & $* * *$ \\
\hline West Virginia & 8 & 33.404 & $* * *$ & 6.966 & & 38.472 & $* * *$ & 23.924 & $* * *$ & 14.147 & $* *$ & 32.255 & $* * *$ \\
\hline Wisconsin & 8 & 22.77 & $* * *$ & 22.77 & $* * *$ & 16.026 & $* *$ & 12.937 & & 12.937 & & 14.667 & $*$ \\
\hline Wyoming & 4 & 9.934 & $* *$ & 9.934 & $* *$ & 7.896 & $*$ & 1.305 & & 1.305 & & 2.396 & \\
\hline $\begin{array}{l}\text { Fisher test } \\
\text { statistic value }\end{array}$ & & 540.201 & & & & & & 505.618 & & & & & \\
\hline $\mathrm{AIC} \operatorname{dmax}=1$ & & CV $1 \%$ & & CV 5\% & & CV10\% & & CV $1 \%$ & & CV 5\% & & CV10\% & \\
\hline & & 281.844 & & 212.179 & & 176.999 & & 247.208 & & 188.594 & & 163.684 & \\
\hline $\begin{array}{l}\text { Fisher test } \\
\text { statistic value }\end{array}$ & & 361.418 & & & & & & 243.683 & & & & & \\
\hline $\mathrm{SBC} d \max =1$ & & $\mathrm{CV} 1 \%$ & & CV 5\% & & CV10\% & & $\mathrm{CV} 1 \%$ & & CV 5\% & & CV10\% & \\
\hline & & 196.409 & & 162.499 & & 146.44 & & 187.813 & & 157.424 & & 142.62 & \\
\hline $\begin{array}{l}\text { Fisher test } \\
\text { statistic value }\end{array}$ & & 419.744 & & & & & & 599.351 & & & & & \\
\hline $\mathrm{AIC} d \max =2$ & & CV $1 \%$ & & CV 5\% & & CV10\% & & CV $1 \%$ & & CV 5\% & & CV10\% & \\
\hline & & 251.99 & & 194.244 & & 168.82 & & 230.001 & & 179.012 & & 156.34 & \\
\hline
\end{tabular}

Note: $1 . * * *, * *$, and $*$ indicate significance at the $0.01,0.05$ and 0.1 levels, respectively.

2 . Bootstrap critical values are obtained from 10,000 replications. 
Table 7. Results of Granger causality between Personal Income and Top 1\% Income Share

\begin{tabular}{|c|c|c|c|c|c|c|c|c|c|c|c|c|c|}
\hline \multirow[t]{2}{*}{ state } & \multirow{2}{*}{$\begin{array}{l}\text { Lag } \\
\text { length }\end{array}$} & \multicolumn{6}{|c|}{$\begin{array}{l}\text { Income led hypothesis } \\
\text { H0: Income sorted does not } \\
\text { Granger Cause Top } 1\end{array}$} & \multicolumn{6}{|c|}{$\begin{array}{c}\text { Inequality led hypothesis } \\
\text { H0: Top1 does not } \\
\text { Granger Cause Income sorted }\end{array}$} \\
\hline & & $\begin{array}{c}\text { AIC, } \\
\mathrm{dmax}=1\end{array}$ & & $\begin{array}{c}\mathrm{SBC}, \\
\mathrm{dmax}=1\end{array}$ & & $\begin{array}{c}\text { AIC, } \\
\mathrm{dmax}=2\end{array}$ & & $\begin{array}{c}\text { AIC, } \\
\mathrm{dmax}=1\end{array}$ & & $\begin{array}{c}\mathrm{SBC}, \\
\mathrm{dmax}=1\end{array}$ & & $\begin{array}{c}\text { AIC, } \\
\mathrm{dmax}=2\end{array}$ & \\
\hline Alabama & 7 & 1.589 & & 3.441 & & 3.002 & & 8.4 & & 12.367 & * & 8.765 & \\
\hline Arizona & 8 & 3.085 & & 1.171 & & 2.81 & & 12.114 & & 8.644 & & 13.969 & $*$ \\
\hline Arkansas & 5 & 4.021 & & 1.729 & & 4.141 & & 2.751 & & 14.038 & $* *$ & 2.889 & \\
\hline California & 4 & 4.822 & & 1.997 & & 4.567 & & 2.72 & & 2.968 & & 3.279 & \\
\hline Colorado & 8 & 5.045 & & 3.553 & & 4.247 & & 11.044 & & 26.372 & $* * *$ & 15.286 & $*$ \\
\hline Connecticut & 8 & 6.533 & & 2.746 & & 6.961 & & 9.724 & & 0.637 & & 14.425 & $*$ \\
\hline Delaware & 8 & 24.83 & $* * *$ & 10.129 & $* * *$ & 23.733 & $* * *$ & 16.53 & $* *$ & 29.735 & $* * *$ & 17.553 & $* *$ \\
\hline Florida & 8 & 9.556 & & 0.661 & & 8.566 & & 16.181 & $* *$ & 21.731 & $* * *$ & 19.259 & $* *$ \\
\hline Georgia & 8 & 9.142 & & 0.613 & & 6.551 & & 8.402 & & 1.759 & & 8.126 & \\
\hline Idaho & 8 & 12.271 & & 12.271 & & 10.03 & & 8.483 & & 7.425 & & 6.839 & \\
\hline Illinois & 5 & 6.068 & & 6.633 & & 6.024 & & 2.882 & & 6.489 & & 2.65 & \\
\hline Indiana & 8 & 7.68 & & 6.222 & & 7.522 & & 9.708 & & 7.723 & & 8.48 & \\
\hline Iowa & 8 & 3.909 & & 0.361 & & 4.338 & & 3.878 & & 6.783 & & 4.93 & \\
\hline Kansas & 8 & 7.055 & & 7.055 & & 7.07 & & 21.101 & $* * *$ & 23.557 & $* * *$ & 16.936 & $* *$ \\
\hline Kentucky & 7 & 4.56 & & 2.625 & & 4.028 & & 5.239 & & 2.809 & & 6.035 & \\
\hline Louisiana & 8 & 8.162 & & 9.803 & $* *$ & 5.212 & & 15.234 & $*$ & 12.186 & $* *$ & 19.918 & $* *$ \\
\hline Maine & 6 & 16.135 & $* *$ & 16.135 & $* *$ & 15.288 & $* *$ & 19.316 & $* * *$ & 17.875 & $* * *$ & 17.14 & $* * *$ \\
\hline Maryland & 6 & 4.335 & & 3.415 & & 4.945 & & 5.806 & & 4.586 & & 6.544 & \\
\hline Massachusetts & 4 & 4.282 & & 2.801 & & 3.744 & & 2.779 & & 1.471 & & 4.755 & \\
\hline Michigan & 5 & 3.7 & & 3.7 & & 4.628 & & 5.592 & & 8.879 & & 6.211 & \\
\hline Minnesota & 8 & 5.384 & & 1.912 & & 5.515 & & 4.774 & & 2.746 & $*$ & 4.211 & \\
\hline Mississippi & 8 & 6.312 & & 2.783 & & 7.822 & & 9.045 & & 10.583 & $*$ & 5.739 & \\
\hline Missouri & 4 & 3.161 & & 3.161 & & 2.731 & & 1.769 & & 8.342 & $*$ & 2.193 & \\
\hline Montana & 8 & 10.077 & & 0.073 & & 8.698 & & 9.828 & & 0.1 & & 8.523 & \\
\hline Nebraska & 8 & 1.93 & & 0.005 & & 2.021 & & 7.544 & & 3.072 & $*$ & 9.652 & \\
\hline Nevada & 8 & 7.084 & & 0.293 & & 8.827 & & 23.573 & $* * *$ & 0.138 & & 20.844 & $* * *$ \\
\hline N. Hampshire & 8 & 10.235 & & 1.786 & & 8.009 & & 8.032 & & 4.621 & & 8.356 & \\
\hline New Jersey & 4 & 1.815 & & 2.282 & & 1.081 & & 1.508 & & 1.269 & & 2.03 & \\
\hline New Mexico & 8 & 18.437 & $* *$ & 8.041 & $*$ & 9.698 & & 10.858 & & 6.896 & & 6.445 & \\
\hline New York & 4 & 1.812 & & 1.812 & & 2.449 & & 7.313 & & 12.578 & $* *$ & 10.742 & $* *$ \\
\hline North Carolina & 8 & 5.992 & & 2.062 & & 6.143 & & 5.065 & & 18.847 & $* * *$ & 3.938 & \\
\hline North Dakota & 3 & 4.589 & & 0.333 & & 2.952 & & 4.465 & & 12.061 & $* * *$ & 3.169 & \\
\hline Ohio & 8 & 4.846 & & 3.608 & & 4.238 & & 11.844 & & 4.728 & & 8.733 & \\
\hline Oklahoma & 8 & 13.094 & & 2.618 & & 8.503 & & 17.758 & $* *$ & 8.8 & $*$ & 14.247 & $*$ \\
\hline Oregon & 7 & 3.07 & & 2.386 & & 3.056 & & 6.138 & & 9.523 & & 3.97 & \\
\hline Pennsylvania & 8 & 8.559 & & 3.489 & & 7.554 & & 9.134 & & 13.136 & $* *$ & 6.779 & \\
\hline Rhode Island & 8 & 12.245 & & 3.15 & & 14.969 & $*$ & 10.821 & & 0.557 & & 13.925 & $*$ \\
\hline South Carolina & 8 & 11.607 & & 3.119 & & 8.816 & & 17.616 & $* *$ & 27.277 & $* * *$ & 15.228 & $*$ \\
\hline South Dakota & 8 & 6.436 & & 0.482 & & 7.494 & & 7.212 & & 5.708 & & 6.065 & \\
\hline Tennessee & 5 & 3.672 & & 2.078 & & 4.306 & & 2.553 & & 9.857 & $*$ & 2.403 & \\
\hline Texas & 8 & 11.923 & & 5.789 & & 7.823 & & 12.666 & & 1.544 & & 13.357 & \\
\hline Utah & 8 & 4.526 & & 1.744 & & 5.289 & & 11.59 & & 2.883 & & 11.91 & \\
\hline Vermont & 8 & 10.701 & & 1.466 & & 13.955 & $*$ & 7.277 & & 0.932 & & 7.472 & \\
\hline Virginia & 8 & 15.118 & $*$ & 1.624 & & 13.945 & $*$ & 20.689 & $* * *$ & 0.994 & & 18.323 & $* *$ \\
\hline Washington & 8 & 3.576 & & 4.266 & & 3.306 & & 10.145 & & 15.208 & $* *$ & 8.75 & \\
\hline West Virginia & 5 & 2.79 & & 2.79 & & 2.646 & & 4.616 & & 14.147 & $* *$ & 5.102 & \\
\hline Wisconsin & 8 & 6.976 & & 3.481 & & 7.889 & & 5.833 & & 12.937 & & 6.251 & \\
\hline Wyoming & 4 & 18.231 & $* * *$ & 18.231 & $* * *$ & 12.839 & $* *$ & 0.449 & & 1.305 & & 0.675 & \\
\hline $\begin{array}{l}\text { Fisher test } \\
\text { statistic value }\end{array}$ & & 115.424 & & & & & & 149.679 & & & & & \\
\hline $\mathrm{AIC} \operatorname{dmax}=1$ & & CV $1 \%$ & & CV 5\% & & CV10\% & & $\mathrm{CV} 1 \%$ & & CV 5\% & & CV10\% & \\
\hline & & 234.786 & & 179.873 & & 158.107 & & 200.43 & & 164.751 & & 146.759 & \\
\hline $\begin{array}{l}\text { Fisher test } \\
\text { statistic value }\end{array}$ & & 116.696 & & & & & & 87.923 & & & & & \\
\hline $\mathrm{SBC} d \max =1$ & & $\mathrm{CV} 1 \%$ & & CV 5\% & & CV10\% & & $\mathrm{CV} 1 \%$ & & CV 5\% & & CV10\% & \\
\hline & & 205.197 & & 165.423 & & 147.754 & & 192.178 & & 156.461 & & 139.868 & \\
\hline $\begin{array}{l}\text { Fisher test } \\
\text { statistic value }\end{array}$ & & 95.33 & & & & & & 148.621 & & & & & \\
\hline $\mathrm{AIC} d \max =2$ & & CV $1 \%$ & & CV 5\% & & CV10\% & & CV $1 \%$ & & CV 5\% & & CV10\% & \\
\hline & & 227.524 & & 176.982 & & 154.646 & & 203.913 & & 164.843 & & 147.944 & \\
\hline
\end{tabular}

Note: $1 . * * *, * *$, and $*$ indicate significance at the $0.01,0.05$ and 0.1 levels, respectively.

2 . Bootstrap critical values are obtained from 10,000 replications. 
Table 8. List of states which cannot reject $\mathrm{HO}$

\begin{tabular}{|c|c|}
\hline Income does not Granger cause Atkinson Index & Atkinson Index does not Granger cause Income \\
\hline $\begin{array}{l}\text { Arizona, Florida, Maryland, Missouri, New } \\
\text { Hampshire, Wyoming }\end{array}$ & New Mexico, North Dakota, Wyoming \\
\hline Income does not Granger cause Gini Coefficient & Gini Coefficient does not Granger cause Income \\
\hline $\begin{array}{l}\text { Arkansas, Colorado, Iowa, Louisiana, Maryland, } \\
\text { Mississippi, Missouri, South Carolina, Texas, } \\
\text { Wisconsin, Wyoming }\end{array}$ & Kansas, Montana, Nebraska, Wyoming \\
\hline $\begin{array}{l}\text { Income does not Granger cause the Relative Mean } \\
\text { Deviation }\end{array}$ & $\begin{array}{l}\text { the Relative Mean Deviation does not Granger } \\
\text { cause Income }\end{array}$ \\
\hline Iowa, Texas, Wyoming & South Dakota \\
\hline $\begin{array}{l}\text { Income does not Granger cause Theil's entropy } \\
\text { Index }\end{array}$ & $\begin{array}{l}\text { Theil's entropy Index does not Granger cause } \\
\text { Income }\end{array}$ \\
\hline $\begin{array}{l}\text { Arizona, Colorado, Connecticut, Florida, Idaho, } \\
\text { Indiana, Iowa, Louisiana, Maryland, Massachusetts, } \\
\text { Minnesota, Mississippi, Missouri, Nevada, New } \\
\text { Hampshire, New Jersey, New York, North Dakota, } \\
\text { Ohio. Oregon. Pennsylvania, South Carolina, South } \\
\text { Dakota, Tennessee, Texas, Utah, Vermont, } \\
\text { Washington, Wisconsin, Wyoming }\end{array}$ & $\begin{array}{l}\text { Arkansas, Idaho, Indiana, Maryland, Mississippi, } \\
\text { Nebraska, New Mexico, North Carolina, Oregon, } \\
\text { South Dakota, Vermont, Wyoming }\end{array}$ \\
\hline $\begin{array}{l}\text { Income does not Granger cause Top } 10 \% \text { income } \\
\text { share }\end{array}$ & $\begin{array}{l}\text { Top } 10 \% \text { income share does not Granger cause } \\
\text { Income }\end{array}$ \\
\hline Arizona, Florida, New York, Utah & Arizona, Montana, South Dakota, Wyoming \\
\hline $\begin{array}{l}\text { Income does not Granger cause Top } 1 \% \text { income } \\
\text { share }\end{array}$ & $\begin{array}{l}\text { Top } 1 \% \text { income share does not Granger cause } \\
\text { Income }\end{array}$ \\
\hline $\begin{array}{l}\text { Alabama, Arizona, Arkansas, California, Colorado, } \\
\text { Connecticut, Florida, Georgia, Idaho, Illinois, Indiana, } \\
\text { Iowa, Kansas, Kentucky, Maryland, Massachusetts, } \\
\text { Michigan, Minnesota, Mississippi, Missouri, Montana, } \\
\text { Nebraska, Nevada, New Hampshire, New Jersey, New } \\
\text { York, North Carolina, North Dakota, Ohio, Oklahoma, } \\
\text { Oregon, Pennsylvania, South Carolina, South Dakota, } \\
\text { Tennessee, Texas, Utah, Washington, West Virginia, } \\
\text { Wisconsin, Wyoming }\end{array}$ & $\begin{array}{l}\text { California, Georgia, Idaho, Illinois, Indiana, Iowa, } \\
\text { Kentucky, Maryland, Massachusetts, Michigan, } \\
\text { Montana, New Hampshire, New Jersey, New Mexico, } \\
\text { Ohio, Oregon, South Dakota, Texas, Utah, Vermont } \\
\text { Wisconsin, Wyoming }\end{array}$ \\
\hline
\end{tabular}

